\title{
A selective alpha1D-adrenoreceptor antagonist inhibits human prostate cancer cell proliferation and motility "in vitro".
}

Alessandra Colciago ${ }^{\mathrm{a}}$, Ornella Mornati $^{\mathrm{a}}$, Nicola Ferri ${ }^{\mathrm{c}}$, Luca Castelnovo ${ }^{\mathrm{a}}$, Laura Fumagalli $^{\mathrm{b}}$, Cristiano Bolchi ${ }^{\mathrm{b}}$, Marco Pallavicini $^{\mathrm{b}}$, Ermanno Valoti $^{\mathrm{b}}$, Paola Negri-Cesi $^{\mathrm{a}^{*}}$

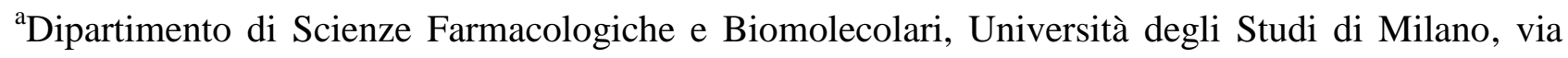
Balzaretti, 9, 20133, Milano, Italy.

${ }^{\text {b}}$ Dipartimento di Scienze Farmaceutiche, Università degli Studi di Milano, via Mangiagalli 25, 20133, Milano, Italy

${ }^{\mathrm{c}}$ Dipartimento di Scienze del Farmaco, Università degli Studi di Padova, Largo Meneghetti 2, 35131, Padova, Italy

${ }^{*}$ Corresponding author at Dipartimento di Scienze Farmacologiche e Biomolecolari, Università degli Studi di Milano, via Balzaretti 9, 20133, Milano, Italy

phone: $+39-0250318209$

fax: +39-0250318204

e-mail: paola.negricesi@unimi.it 


\section{ABSTRACT}

The progression of prostate cancer (PC) to a metastatic hormone refractory disease is the major contributor to the overall cancer mortality in men, mainly because the conventional therapies are generally ineffective at this stage. Thus, other therapeutic options are needed as alternatives or in addition to the classic approaches to prevent or delay tumor progression. Catecholamines participate to the control of prostate cell functions by the activation of alpha1-adrenoreceptors (alpha1-AR) and increased sympathetic activity has been linked to PC development and evolution. Molecular and pharmacological studies identified three alpha1-AR subtypes (A, B and D), which differ in tissue distribution, cell signaling, pharmacology and physiological role. Within the prostate, alpha1A-ARs mainly control stromal cell functions, while alpha1B- and alpha1D- subtypes seem to modulate glandular epithelial cell growth. The possible direct contribution of alpha1D-ARs in tumor biology is supported by their overexpression in PC. The studies here presented investigate the "in vitro" antitumor action of A175, a selective alpha1D-AR antagonist we have recently obtained by modifying the potent, but not subtype-selective alpha1-AR antagonist (S)-WB4101, in the hormone-refractory PC3 and DU145 PC cell lines. The results indicate that A175 has an alpha1DAR-mediated significant and dose-dependent antiproliferative action that possibly involves the induction of G0/G1 cell cycle arrest, but not apoptosis. In addition, A175 reduces cell migration and adhesiveness to culture plates. In conclusion, our work clarified some cellular aspects promoted by alpha1D-AR activity modulation and supports a further pharmacological approach in the cure of hormone-refractory PC, by targeting specifically this AR subtype.

KEYWORDS: adrenergic system, alpha1D-adrenoreceptor selective antagonist, hormone-resistant human prostate cancer, anticancer activity, "in vitro" cell proliferation, "in vitro" cell migration.

CHEMICAL COMPOUNDS STUDIED IN THIS ARTICLE: Phenylephrine hydrochloride (PubChem CID: 5284443); phenoxybenzamine hydrochloride (PubChem CID: 5284441); docetaxel (PubChem CID: 148124). 


\section{INTRODUCTION}

Despite the intense basic and pharmacological research in these last years, prostate cancer (PC) is still a major contributor to the overall cancer mortality in men, because of tumor progression from an androgen-dependent to an androgen independent/castration resistant phenotype [1]. Conventional therapies for metastatic hormone-refractory PC are mostly palliative and fail to effectively improve the survival rate, at present [2]. Thus, further options are needed as alternatives or in addition to the classic therapeutic approaches to prevent or delay tumor growth, minimizing toxicity.

Alpha1-adrenoreceptors (alpha1-AR), which have been subdivided into three pharmacologically distinct subtypes (alpha1A, alpha1B and alpha1D, [3]), mediate several of the actions exerted by catecholamines on prostate cells, including stroma and epithelial growth, as well as smooth muscle contraction [4]. Increased sympathetic activity has been linked to PC recurrence, progression and aggressiveness (see [5] for references). Moreover, similarly to angiogenesis, new autonomic nerve projections infiltrate the tumor mass, participating to cancer evolution and providing a gateway for cell dissemination (perineural invasion) [6].

Studies on alpha1-AR subtype localization of within the human prostate reveal that alpha1A-ARs predominate in the stroma of the normal and hyperplastic glands [7, 8], where they are involved smooth muscle contraction. On the contrary, the presence of this AR subtype in the normal or neoplastic epithelial cells is still debated [9-14]. Alpha1B- and alpha1D-ARs localize almost exclusively in the epithelial compartment both of normal (PrEc) and neoplastic glands [7, 15], where they control cell growth [13]. Remarkably, alpha1D-ARs are overexpressed in androgenresistant PC cells [11] and in specimens from untreated patients with advanced PC [16].

After being initially introduced for the management of hypertension, alpha1-AR antagonists have been successively targeted to the treatment of benign prostatic hyperplasia (BPH) and lower urinary tract symptoms (LUTS) [17]. The first observations on the antiproliferative effect of alpha1-AR antagonists in PC date back to early 2000, when quinazoline-based non subtype selective alpha1- 
AR blockers, such as prazosin, doxazosin and terazosin, were proved to stimulate PC cells apoptosis [9, 18-20]. In addition, retrospective clinical studies showed $30 \%$ decrease of the relative risk of PC development in patients treated with alpha1-AR blockers in comparison to untreated patients [21]. The possible additional use of alpha1-AR blockers in prostate related diseases was further promoted by the increasing availability of alpha1A/1D-AR and, more recently, alpha1D-AR selective antagonists with low alpha1B-AR affinity. Since alpha1B-ARs are highly expressed in human vascular bed and their expression increases with age [22], the use of selective alpha1B-AR blockers might develop undesirable side effects. On the contrary, the pharmacological profile of the alpha1A- and alpha1D-AR antagonists reveals slight effects on vascular resistance, particularly in elderly patients $[23,24]$.

The recent intense research has clearly shown that PC growth is reduced both "in vitro" and "in vivo" by some alpha1A/D-AR antagonists (labedipinedilol-A, [25]), or slightly alpha1D- vs. alpha1A-AR antagonists (naftopidil [13, 26-28] and its very recent amide-indole derivatives [29]), or markedly alpha1D-AR antagonists (clopenphendioxan [11] and gem-diphenyl dioxane derivatives $[30,31])$. On the other hand, very potent, but not subtype-specific alpha1-AR blockers, such as WB4101, or also other alpha1D-AR selective antagonists, such as BMY-7378, do not exhibit significant antiproliferative effect on PC cells $[14,30]$. Also the correlation between alpha1AR antagonism and control of PC cells proliferation has not yet been completely elucidated and different action mechanisms have been demonstrated or suggested. The antiproliferative effect of naftopidil and of doxazosin seems to be alpha1-AR independent [9, 18-20, 28], while evidences have been provided that the antitumor activity is alpha1-AR mediated in the case of labedipinediolA [25] as well as of recently reported indolic analogues of naftopidil [29] and of the gemdiphenyldioxane derivatives $[30,31]$.

On the basis that 1- not all the alpha1D-AR antagonists can suppress PC growth and 2- not all the antiproliferative alpha1D-AR antagonists have a receptor-mediated action, we undertook the present study on A175, a new potent and selective alpha1D-AR antagonist we recently discovered 
through a long series of modifications of the well-known potent but not subtype selective alpha1AR antagonist 2-(2,6-dimethoxyphenoxyethylaminomethyl)-1,4-benzodioxane ((S)-WB4101 [3237]). The chemical structures of the two compounds are shown in the box below. A175 has alpha1D/alpha1A and alpha1D/alpha1B antagonist affinity ratios of 129 and 12, respectively, and is devoid of 5-HT1A and alpha2-AR affinity [37]. Aim of the investigation was, firstly, to asses whether this compound can effectively control "in vitro" cell proliferation, motility and survival of androgen-independent PC cells and, if so, to elucidate its action mechanism and the involvement of alpha1D-AR antagonism in these cellular responses.

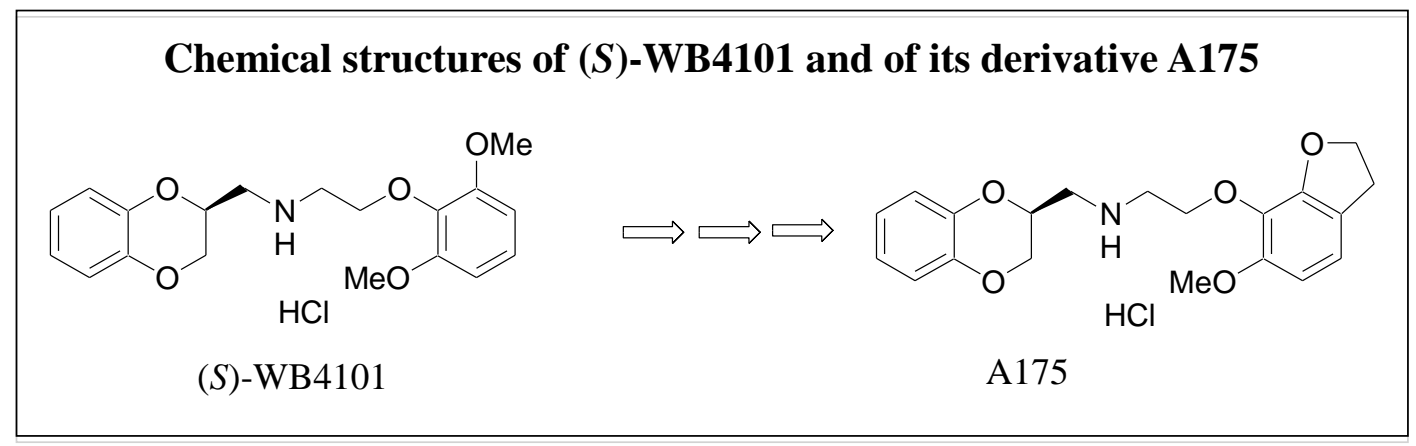

\section{MATERIALS AND METHODS}

\subsection{Cell cultures}

Human androgen independent prostate cancer PC3 and DU145 cell lines and the androgendependent LNCaP cell line were originally obtained from American Type Culture Collection (ATCC, Rockville, MD, USA); CWR22Rv1 (Rv1) cells were originally obtained from LeibnitzInstitut DSMZ (Braunschweig, Germany). All cell lines are currently used in our lab. The experiments were carried out between $30^{\text {th }}$ and $40^{\text {th }}$ in vitro passages.

All cell culture reagents were purchased from EuroClone (Milan, Italy). LNCaP, Rv1, PC3 and DU145 cells were routinely grown at $37^{\circ} \mathrm{C}$ in a humidified atmosphere $\left(5 \% \mathrm{CO}_{2}-95 \%\right.$ air $)$ in 100 mm Petri dishes in RPMI 1640 supplemented with 10\% (PC3, LNCaP) or 5\% (DU145, Rv1) heat inactivated fetal calf serum (FCS), glutamine (2 mM), penicillin (100 IU/mL), streptomycin (100 $\mu \mathrm{g} / \mathrm{mL})$. Medium was changed biweekly. 


\subsection{Chemicals and treatments}

A175 was prepared as previously reported [37], dissolved in water and added at the final concentrations reported in each figure. Phenylephrine hydrochloride, phenoxybenzamine hydrochloride and docetaxel (all from Aldrich Italia, Milan, Italy) were dissolved in water, in ethanol and in DMSO respectively. A175 (different doses) and phenylephrine (final concentration $50 \mu \mathrm{M}$ ) treatments were carried out for $48 \mathrm{~h}$. The irreversible alpha1-AR inhibitor phenoxybenzamine (final concentration $1 \mu \mathrm{M}$ ) was added to the cultures $4 \mathrm{~h}$ before adding A175.

\subsection{Growth rate evaluation}

PC3 and DU145 cells were seeded in 96-well plates (Greiner Bio-One; Frickenhausen, Germany) at a mean concentration of 5,000 cells/well in RPMI 1640 supplemented with $1 \%$ (basal conditions) or $10 \%$ (serum-stimulated conditions) FCS, according to the different protocols (see the relative figures). All treatments were started $24 \mathrm{~h}$ after seeding. Cell proliferation was evaluated by 5bromo-2'-deoxyuridinee (BrdU) cell proliferation assay kit (Delfia, Perkin Elmer, Milan, Italy) according to manufacturer's protocol. Results, expressed as fluorescence emission/second (rlu/second), were obtained by determining the mean value of at least 6 independent samples/group/experiment.

\subsection{Cell toxicity and apoptosis}

Cytotoxicity of A175 was evaluated in two independent experiments by the CellTox Green Cytotoxicity Assay (Promega Italia, Milan, Italy), according to manufacturer's protocol. Briefly, PC3 cells were seeded in 96-well plates (4,500 cells/well) in RPMI containing either 1\% or 10\% FCS and treated with graded doses of A175 (least 8 wells/group) for $48 \mathrm{~h}$. Untreated cell lysate was used as positive control of cytotoxicity. Cell fluorescence were measured in a MultiMode Plate Reader (EnSpire, Perkin Elmer, Milan, Italy). 
Apoptosis activation by A175 was evaluated by a chemoluminescent assay (Caspase-Glo 3/7 Assay, Promega Italia, Milan, Italy), according to manufacturer's protocol. PC3 cells were plated in 96well plates $(5,000$ cell/well) and treated for $48 \mathrm{~h}$ with 25 or $50 \mu \mathrm{M}$ A175 either in basal (1\% FCS) or in serum-stimulated (10\% FCS) conditions. The luminescent signal was measured in a luminescence counter (MicroBeta ${ }^{\circledR}$, Perkin Elmer, Milan, Italy). Cells treated with Docetaxel 50 $\mathrm{nM}$ for 48 or $72 \mathrm{~h}$ provided positive controls for apoptosis [38]. At least 8 wells/group in two independent experiments were used.

\subsection{Reverse transcriprion-real time PCR ( $q P C R)$}

Total RNA from LNCaP, Rv1, PC3 and DU145 was extracted by the phenol-chloroform method according to standard protocols [39]. A mean of 2 independent RNA samples were used for each determination. Reverse transcription was performed on $1 \mu \mathrm{g}$ of total RNA from each sample according to the manufacturer's protocol (iScript cDNA synthesis kit, BioRad, Segrate, Italy) using random primers. qPCR was done in singleplex in CFX96 Touch ${ }^{\mathrm{TM}}$ Real-Time PCR Detection System (BioRad, Segrate, Italy) by using SYBR Green dye (SsoAdvanced SYBR Green Supermix, Bio-Rad, Segrate, Italy). The specific set of primers are listed in Table 1. Data analysis was performed using the CFX Manager 2.0 software (Bio-Rad, Segrate, Italy). Each sample was analysed in triplicate.

Table 1: primer sequences

\begin{tabular}{|l|l|l|}
\hline Target gene & Forward primer & Reverse primer \\
\hline alpha1A-AR & AGTCATGCCCATTGGGTCTTT & ATGGGGTTGATGCAGCTGTT \\
\hline alpha1B-AR & CCTGAGGATCCATTCCAAGA & CGGTAGAGCGATGAAGAAGG \\
\hline alpha1D-AR & GTGCGCCACTCACTCAAGTA & GAGCACACGGAGGAGAAGAC \\
\hline Beta-actin & CCACCATGTACCCTGGCATT & CGGACTCGTCATACTCCTGC \\
\hline
\end{tabular}


For each AR subtype the relative CT was normalized for beta-actin CT. Relative mRNA levels were then calculated by the comparative CT method $\left(2^{-\Delta \Delta C t}\right)$ using as calibrator a sample of total RNA pooled from all PC cells [40].

\subsection{Cell cycle analysis}

Flow cytometry was used to analyze cell cycle distribution. PC3 and DU145 cells were seeded in 30 mm Petri dishes (150,000 cells/dish) in RPMI containing either 10\% (PC3) or 5\% (DU145) FCS and treated with graded doses of A175 (least 4 samples/group) for 48 h. After trypsinization, cells were resuspended in $0.5 \mathrm{ml}$ of permeabilizing buffer of Sytox Dye $(0.5 \mu \mathrm{M}$ in $100 \mathrm{mM}$ Tris, $\mathrm{pH} 7.4$, $150 \mathrm{mM} \mathrm{NaCl}, 1 \mathrm{mM} \mathrm{CaCl} 2,0.5 \mathrm{mM} \mathrm{MgCl} 2$, and $0.1 \%$ Nonidet P-40). Samples were placed in the dark for $15 \mathrm{~min}$, and the fluorescence of individual nuclei was measured. Nuclear Sytox Dye (Molecular Probe, Pittsburgh, PA) fluorescence signal was recorded on the FL2 channel of a FACScan flow cytometer (BD Biosciences, San Jose, CA) and analyzed with ModFit LT software (Verity Software House, Topsham, ME). The number of cells in G0/G1, S, and G2/M phases was expressed as percentages of total events (10,000 cells).

\subsection{Western blot analysis}

Control and treated cell lysates were prepared in RIPA buffer added with protease inhibitors. Equal amounts of total protein extracts (30 $\mathrm{g} / \mathrm{sample}$ ), as determined by BCA method (Pierce, Rockford, IL, USA), were resolved on SDS-PAGE and electro-transferred to nitrocellulose membrane. Membranes were blocked with 5\% non fat dry milk in tris-buffered saline for $1 \mathrm{~h}$ before incubation overnight with the following primary antibodies: rabbit anti human p21 and p27 (1:750; Cell Cycle Regulation Sampler Kit, Cell Signaling Technology, EuroClone, Milan, Italy) and mouse anti human beta-actin (1:500; Abcam, Cambridge, UK). Immunoreactivity was detected by the fluorescent qDot system (Life Technologies Italia, Monza, Italy). Beta-actin was used to normalize target protein levels. Densitometric analysis of the fluorescent bands was performed using Image J 
software. Four independent PC3 samples/group, obtained in two different experiments, were analyzed.

\subsection{Cell motility assay}

The influence of a $48 \mathrm{~h}$ treatment with A175 on PC3 and DU145 cell motility was evaluated in a Boyden chamber (Neuro Probe Inc., Gaithersburg, MD, USA) containing $8 \mu \mathrm{m}$ polyvinylpyrrolidone-free polycarbonate filters precoated with gelatin $(0.2 \mathrm{mg} / \mathrm{mL}$ in PBS $) 5$ day before and maintained at $4{ }^{\circ} \mathrm{C}$ until use. After $48 \mathrm{~h}$ exposure to vehicle or A175 (10 or $\left.50 \mu \mathrm{M}\right)$ cells

were harvested, counted, resuspended in DMEM $+0.1 \%$ BSA at the same concentration of $2,000,000$ cells $/ \mathrm{mL}$ and plated in the upper compartment of the Boyden chamber $(100,000$ cells/well). The lower compartment was filled either with DMEM or with DMEM+FCS 1\% (28 $\mu \mathrm{L} /$ well) to assess chemokinesis and chemotaxis respectively. After migration (overnight at $37^{\circ} \mathrm{C}$ ), cells adherent to the lower membrane surface were fixed with methanol, stained according to the Diff-Quik kit (Biomap, Agrate, Italy) and counted in standard optical microscopy (40x). Three random objective fields of stained cells were counted for each well and the mean number of migrating cells $/ \mathrm{mm}^{2}$ was calculated. The cell motility assay was repeated three times (at least 6 independent sample/group/experiment).

\subsection{Cell adhesion assay}

After $48 \mathrm{~h}$ exposure to vehicle or A175 $(10$ or $50 \mu \mathrm{M})$ cells were collected, counted and seeded in 24-well uncoated plates at the same concentration of 40,000 cells/well. Cells were allowed to attach to the plates during a $4 \mathrm{~h}$ incubation period at $37^{\circ} \mathrm{C}$. After this period, non-attached cells were carefully washed away and the number of the remaining attached living cells was evaluated by 3(4,5-dimethylthiazol-2-yl)-2,5-diphenyl tetrazolium bromide (MTT) colorimetric assay. Cell adhesion assay was repeated twice (8 independent sample/group/experiment). 


\subsection{Immunofluorescence and confocal laser scan microscopy}

Control and A175 treated PC3 cells, seeded on slides, were fixed in 4\% paraformaldehyde in PBS for $10 \mathrm{~min}$ at room temperature and processed for alpha1D-AR immunostaining. Cells were permeabilized with Triton 0,3\% in PBS (15 min, RT), blocked with 5\% Normal Goat Serum in PBS/0.1\% Tween-20 and incubated $\left(4^{\circ} \mathrm{C}\right.$, overnight $)$ with anti alpha1D-AR primary antibody (1:50, Santa Cruz Biotechnology, Heidelberg, Germany). Alexa Fluor 488 conjugate was used as secondary antibody $\left(1: 100,1 \mathrm{~h}, 37^{\circ} \mathrm{C}\right.$; Thermo Scientific, Rockford, IL, USA). After washing, slides were mounted using Vectashield ${ }^{\mathrm{TM}}$ (Vector Laboratories, Burlingame, CA, USA). Control of the specificity of the antibody included a lack of primary antibody. Confocal microscopy was carried out using a Zeiss LSM 510 System (Gottingen, Germany) and images were processed with Image plus 6.0.

\subsection{Statistical analysis}

The statistical analysis of the row data was performed by one way ANOVA and expressed as mean \pm SD. Post-hoc analysis was performed by Tukey's Multiple Comparison Test, using the Prism4 software for Macintosh (GraphPad Software, San Diego, CA). Only p values $<0.05$ were considered statistically significant. The same software was used to calculate dose-response curves.

\section{RESULTS}

\subsection{Expression of alphal-AR subtypes}

The relative expression pattern of the three alpha1-AR subtypes in the main androgen-dependent (LNCaP), androgen-sensitive (Rv1) and androgen-independent (PC3, DU145) PC cell lines is shown in figure $1 \mathrm{~A}$. It appears that the alpha1A-AR subtype is present almost exclusively in the two cell lines that are still dependent/sensitive to androgens (Rv1 > LNCaP), is lower in DU145 and absent in PC3 cells. Conversely, alpha1B- and alpha1D-AR subtypes seems to be present only in the two androgen-independent cell lines (alpha1B-AR DU145 >> PC3; alpha1D-AR confined in 
PC3 cells). A second qPCR experiment limited to DU145 and PC3 cells better clarified the relative expression pattern of alpha1B-AR and alpha1D-AR subtypes in these two cell lines (figure 1B). In this case, RNA pooled only from PC3 and DU145 cells was used as calibrator. Also in this experiment it is clear that alpha1B-AR expression is 3 times higher in DU145 than in PC3 cells, while alpha1D-AR is expressed only in PC3 cells.

\subsection{Effects on PC cell proliferation}

The alpha1D-AR mediated antiproliferative action of A175 was assessed in PC3 cells both in basal (cells maintained in 1\% FCS, figure 2A) or in growth-stimulating (cells maintained in $10 \%$ FCS, figure 2B) conditions. DU145 cells provided negative controls. As shown in figure $2 \mathrm{~A}$, a $48 \mathrm{~h}$ treatment with grading doses of A175 induces a progressive decrease of PC3 cell growth, which became highly significant from $10 \mu \mathrm{M}$ onward. In the $10-75 \mu \mathrm{M}$ interval each concentration is significantly more active that the previous one. The same significant inhibitory activity of 25 and 50 $\mu \mathrm{M}$ A175 on PC3 cell growth is evident also in growth-stimulating conditions (figure $2 \mathrm{~B}$, left side). Conversely, A175 administered at the same concentration and treatment length is completely ineffective on DU145 cell growth (figure 2B, right side), suggesting that the antiproliferative action of A175 is alpha1D-AR mediated. A test performed in PC3 cells maintained either in $1 \%$ or in $10 \%$ FCS excluded a possible nonspecific cytotoxic effect of $48 \mathrm{~h} \mathrm{A175}$ exposure even at the dose of 75 $\mu \mathrm{M}$, which blocks almost completely cell proliferation (data not shown).

To further assess the possible dependency of A175 action on alpha1D-AR binding, PC3 cells, maintained in $10 \%$ FCS medium, were stimulated to proliferate with phenylephrine (figure $3 \mathrm{~A}$ ) or were pretreated with the irreversible alpha1-AR antagonist phenoxybenzamine (figure 3B). As shown in the figure, the dose-dependent antiproliferative action of A175 alone in PC3 cell is apparent once again (left sides of panels A and B). As expected, phenylephrine stimulates cell proliferation, an effect that is significantly and dose-dependently counteracted by A175 (figure 3A, right side). From figure 3B (right side) it is apparent that PC3 pretreatment with phenoxybenzamine 
(PBA) at the dose of $1 \mu \mathrm{M}$ for $4 \mathrm{~h}$ does not influence cell growth; the exposure to PBA prior to the $48 \mathrm{~h}$ treatment with A175 reduces, but does not completely block, the antigrowth action of the compound.

Since A175 does not seem to induce caspase-associated apoptosis (not shown), we evaluated by FACScan analysis the effect of $48 \mathrm{~h} \mathrm{A175}$ exposure on PC3 and DU145 cell distribution along cell cycle (figure 4). Panels A and C report both the representative histograms of each experimental group and the cumulative results obtained in two independent experiments. The statistical analysis of the cumulative data shows that A175 exposure progressively increases the amount of PC 3 cells in the G0/G1 phase, with an effect that becomes significant at the higher dose (panel A). Conversely, no significant modifications were assessed in treated DU145 cells (panel C). In the same figure, panels B and D report a representative Western blot and the densitometric analysis of p21 and p27 levels in PC3 and DU145 cells respectively. The mean doubling of p27 and p21 levels in treated PC3 (panel B) but not in DU145 cells (panel D) strengthen the results obtained by FACScan analysis.

\subsection{Effects on PC cell motility and adhesion}

The ability of a 48 h treatment with A175 to modulate cell motility of PC3 and DU145 cells was investigated by microchemotaxis assay, evaluating, in separate experiments, either the spontaneous motility (chemokinesis) or the motility stimulated by a chemoattractant (FCS 1\%). In this set of experiments A175 was used at the doses of 10 and $50 \mu \mathrm{M}$. As shown in figure 5, the presence of the chemoattractant increases the motility of both cell lines of about 5-6 times (DMEM vs FCS 1\% control columns in panels A and B). Pretreatment with A175 neither at 10 nor at $50 \mu \mathrm{M}$ is able to influence the spontaneous motility of PC3 and DU145 cells (data not shown); on the contrary, the two cell lines respond differently to the compound in chemotaxis experiments: PC 3 cells show a highly significant and dose-dependent reduction of migration (figure 5A), while DU145 motility is unaffected (figure 5B). 
A specific assay allowed identifying the effect A175 on the "in vitro" adhesion potential of PC3 cells to uncoated culture plates. Figure 6 reports the percent of control and treated cells attached to the plate $4 \mathrm{~h}$ after re-seeding: cell attachment is significantly and dose-dependently reduced by a previous $48 \mathrm{~h}$ exposure to A175 at 10 and $50 \mu \mathrm{M}$ (20\% and $40 \%$ inhibition of cell attachment, respectively).

\subsection{Effects on alphalD-AR cell localization}

The possible influence of A175 on alpha1D-AR localization within PC3 cells is shown in figure 7. Confocal analysis shows that in control cells alpha1D-AR is present in the nucleus and in small spots in the perinuclear region (*). After A175 treatment nuclear stain is maintained, while larger spots (more evident with the higher dose) appear in the whole cell body (**).

\section{DISCUSSION}

The relative expression pattern of alphal-AR subtypes either in normal or in neoplastic human prostate is unclear from the literature, depending on the methods adopted (binding studies using high or low selective blockers, Western blots, immunohistochemistry, immunolocalization, etc.). To identify the best cell model to be used in our studies, we initially evaluated simultaneously the relative expression levels of the three alpha1-AR subtypes in the main androgen-sensitive or independent PC cell lines commercially available. According to some authors [9-12, 14], the major finding of our qPCR studies is that alpha1A-AR mRNA is present in less aggressive and still androgen sensitive PC cells (LNCaP and RV1), while it is absent, or present at lower levels, in the more aggressive androgen-independent DU145 and PC3 cells. Moreover, we demonstrate for the first time that this AR subtype is much more expressed in cells derived from a primary PC lesion (RV1) than in cells derived from metastatic sites (LNCaP and DU145), suggesting that selective alpha1A-AR blockers might be more useful to counteract cell proliferation in tissue-confined than in metastatic PC. In general agreement with the literature $[11,12,41]$, our results also demonstrate 
that alpha1B- and alpha1D-AR subtypes are expressed only in the androgen-independent PC cells, but with a different distribution: alpha1B-AR RNA appears almost exclusively in DU145, while alpha1D-AR is confined in PC3 cells. It should be underlined, however, that the presence of alpha1D-AR only in one of the PC cell lines tested does not ruled out its involvement in PC biology. Indeed, the overexpression of alpha1D-AR in many specimens from untreated patients with advanced PC [16] proves that this AR subtype is a valid target for PC treatment. As PC3 are the only PC cells expressing alpha1D-AR, we selected this cell line to evaluate specifically A175 action.

When PC3 cells have been maintained in basal proliferative conditions (FCS 1\%), A175 dosedependently reduced cell growth, with a calculated IC50 of $19 \mu \mathrm{M}$. As expected, the antiproliferative action of the compound in PC3 cells maintained in growth-stimulating conditions (FCS 10\%) is still dose-dependent, but less effective, with a mean reduction of cell proliferation of 18 and $37 \%$ at doses of 25 and $50 \mu \mathrm{M}$, respectively. In these culture conditions, A175 seems to have a reduced potency compared to less specific alpha1-AR antagonists [9, 27] or to other selective alpha1D-AR blockers $[11,29]$, the IC50 of which ranges from 2 to $30 \mu \mathrm{M}$. However, doxazosin, terazosin, as well as naftopidil and its related compounds, reduce the growth rate also of DU145 and LNCaP cells [26, 27, 29], which, as previously discussed, lack alpha1D-ARs. It might be possible that all these compounds act either by interacting with other AR subtypes, or through an AR-independent mechanism, as suggested by many authors $[9,18,25,28]$.

The same A175 concentrations that significantly and dose-dependently reduce PC 3 proliferation are completely unable to influence DU145 cell growth. As, in our hands, these cells are devoid of alpha1D-AR, this suggests that, as opposed to the other compounds, the antiproliferative activity of A175 is alpha1D-AR-mediated. The selective efficacy of A175 only in cells expressing alpha1DAR might be particularly important in light of the high intrinsic activity typical of this AR subtype demonstrated in other experimental models [42]. 
Similar to noradrenaline $[11,25]$, the alpha1-AR agonist phenylephrine (Phe) has a direct mitogenic effect on PC3 growth (about 130\% over controls). A175 dose-dependently inhibits Phe-stimulated cell proliferation, supporting the alpha1D-AR-mediated action of the compound. To further confirm this issue, we pretreated PC3 cells with the irreversible inhibitor phenoxybenzamine (PBA). The exposure to PBA, which does not affect cell proliferation when given alone, slightly counteracts the antiproliferative action of A175. However, it should be underlined that in PBA pretreated cells A175, at both doses, is less effective in comparison to cells not previously exposed to the inhibitor (proliferation rate in plus vs minus PBA are $16 \%$ vs $20.1 \%$ and $26.7 \%$ vs $37.5 \%$ for A175 25 and $50 \mu \mathrm{M}$ respectively) and looses the dose-response effect. Similarly to our findings, PBA pretreatment also fails to fully counteract the action of other alpha1-AR blockers when given at concentrations higher than $10 \mu \mathrm{M}[9,25]$. Hence, it is possible either that other pretreatment conditions (higher PBA concentrations and/or longer pretreatments) would give different results, or that at least part of A175 action on cell proliferation does not involve alpha1D-AR binding.

As opposed to other alpha1-AR antagonists [9, 25, 29], A175 is completely unable to induce apoptosis of PC3 cells maintained either in basal (RPMI 1\% FCS) or in growth-stimulated (RPMI $10 \%$ FCS) conditions (data not shown). Thus, we evaluated whether, as already demonstrated for naftopidil $[14,26]$, the antiproliferative action of A175 might involve the modulation of cell cycle progression. FACScan analysis demonstrates that only in PC3 A175 exposure specifically induces a progressive increase of cell amount in the G0/G1 phase associated with increased levels of p27 and p21 (two inhibitors of cell cycle progression). Among senescence-associated cell cycle inhibitors, p27 and p21 are deeply involved in prostate growth, so that high p27 and/or p21 levels are independent predictors of favorable prognosis and increased survival in PC patients [43], while their downregulation is typical of high-grade/poor responsive PC [44]. A p21-dependent induction of PC3 senescence has been recently demonstrated as a mechanism of action of other drugs [45] and might account for the above discussed low activity of A175 compared to other pro-apoptotic alpha1-AR antagonists. The cytostatic property of A175 in cells that, as PC3, lack p53 is significant 
since, in the absence of p53-mediated apoptosis, the activation of cellular senescence can still prevent genomic instability [46]. Cell cycle inhibition and/or the enhancement of senescence might be considered an effective chemopreventive strategy to reduce tumor growth and to decrease the risk of further genetic changes.

Given that active migration and the ability to adhere to host tissues are critical determinants for metastasis development and that norepinephrine is a potent inducer of cancer cell migration [47], we tested the ability of A175 to interfere with PC3 chemotaxis and with the cell adhesion properties. A175 has a powerful antimigratory effect (reduction of cell motility of about 53\% and $70 \%$ at doses of 10 and $50 \mu \mathrm{M}$, respectively), which is already evident at concentrations ineffective on cell proliferation. Our preliminary experiments also demonstrate that PC3 exposure to A175 at the same concentrations significantly reduces cell ability to adhere to a new plate. A huge rise of p21 and p27 in normal mesenchymal cells loosing their anchorage has been recently described [48]. It is thus possible that hindering cell mitosis, by increasing p21 and p27, might prevent further cell anchorage by reducing cell adhesion proteins. Studies are ongoing to test this possibility. Quinazoline-based compounds significantly reduce cell motility [49] and adhesion [50, 51] with an action mechanism independent of alpha1-AR activation [49]. Conversely, the lack of efficacy of A175 on DU145 migration is indicative of an alpha1D-AR mediated effect. The induction of senescence and the antimigratory potential of alpha1D-AR selective antagonists, which minimize the metastatic behavior of PC cells, represent important chemopreventive aspects that deserves a more thoroughly evaluation in forthcoming studies.

The multifaceted efficacy of the compound also in the absence of a stimulating effect by catecholamines suggests that A175 might behave as an inverse agonist of a receptor endowed with constitutive activity [3]; this action appears to be different from the neutral antagonist behavior we previously observed for this molecule in other functional tests [34]. As alpha1D-ARs display a prevalent intracellular localization $[3,11,42,52]$, we wondered whether the effect of A175 might be related to modification of receptor trafficking among cell compartments. Confocal microscopy 
shows that, as expected, alpha1D-AR appears in small clusters (cytoplasmic vesicles?) in a prevalent perinuclear localization. After $48 \mathrm{~h}$ of exposure to the compound the receptors appear to be clustered in significantly larger immunoreactive spots scattered in all cell body. As opposed to what demonstrated for other inverse agonists [53], A175 does not seem to influence the redistribution of the receptor from cytoplasm to cell membrane. Our confocal results do not allow to speculate on the cellular pathway(s) activated by A175/alpha1D-AR complex, at present. The mechanism of action of alpha1D-AR in the control of cell proliferation is still elusive, involving either the formation of homo/heterodimers [54], or the crosstalk with other membrane proteins, such as calcium channels [16]. As the majority of the studies on the relationship between alpha1DAR activity and its cell localization have been conducted in transfected in vitro models $[3,52,53]$, further studies should be undertaken to elucidate the functional role of the endogenous receptor and the mechanism(s) through which selective antagonists counteract its activity.

\section{CONCLUSIONS}

Overall, the data obtained strongly support the efficacy of A175 as cytostatic agent, able to reduce cell proliferation interfering with cell cycle progression, to decrease cell motility and to reduce cell adhesion. The inefficacy of the compound in cells lacking alpha1D-AR, as DU145, support the notion that cell response to A175 is mainly receptor-mediated.

Considerable pharmacological efforts have been recently directed toward molecules able to specifically target PC growth and progression, in the attempt to improve chemoprevention and therapeutic response, minimizing toxicity. The studies here presented support a new pharmacological approach for the cure of androgen-independent highly metastatic PC by targeting alpha1D-ARs and suggest that A175 may represent a promising lead compound to design new more potent selective ligands. Further studies need to be done to confirm the anticancer capability of this or other selective alpha1D-AR blockers also in vivo. Moreover, as the ability to prevent PC development in xenograft models [50] and to decrease the incidence of PC in men [21] has been 
demonstrated for alpha1-AR antagonists, future studies should focus on the possible prophylactic value of A175 and/or other selective alpha1D-AR blockers in PC chemoprevention. 


\section{AKNOWLEDGMENTS}

Part of the experiments was supported by the "Piano di sviluppo UNIMI, linea B" to dr. A. Colciago. 


\section{REFERENCES}

[1] L.A. Torre, F. Bray, R.L. Siegel, J. Ferlay, J. Lortet-Tieulent, and A. Jemal, Global cancer statistics, 2012, CA: a cancer journal for clinicians, 65 (2015) 87-108. DOI:10.3322/caac.21262; http://www.ncbi.nlm.nih.gov/pubmed/25651787

[2] M. Kirby, C. Hirst, and E.D. Crawford, Characterising the castration-resistant prostate cancer population: a systematic review, International journal of clinical practice, 65 (2011) 1180-1192. DOI:10.1111/j.1742-1241.2011.02799.x; http://www.ncbi.nlm.nih.gov/pubmed/21995694

[3] P. Hein and M.C. Michel, Signal transduction and regulation: are all alpha1-adrenergic receptor subtypes created equal?, Biochemical pharmacology, 73 (2007) 1097-1106. DOI:10.1016/j.bcp.2006.11.001; http://www.ncbi.nlm.nih.gov/pubmed/17141737

[4] C.W. White, J.H. Xie, and S. Ventura, Age-related changes in the innervation of the prostate gland: implications for prostate cancer initiation and progression, Organogenesis, 9 (2013) 206DOI:215. 10.4161/org.24843; http://www.ncbi.nlm.nih.gov/pubmed/23872639

[5] J. Rao, J. Yang, Z. Liu, L. Wang, Z. Yin, L. Liu, Q. He, and L. Yang, Hypothetic association between greater sympathetic activity and prostate cancer, Medical hypotheses, 71 (2008) 442-443. DOI:10.1016/j.mehy.2008.03.039; http://www.ncbi.nlm.nih.gov/pubmed/18472228

[6] C. Magnon, S.J. Hall, J. Lin, X. Xue, L. Gerber, S.J. Freedland, and P.S. Frenette, Autonomic nerve development contributes to prostate cancer progression, Science, 341 (2013) 1236361. DOI:10.1126/science.1236361; http://www.ncbi.nlm.nih.gov/pubmed/23846904

[7] P.D. Walden, C. Gerardi, and H. Lepor, Localization and expression of the alpha1A-1, alpha1B and alpha1D-adrenoceptors in hyperplastic and non-hyperplastic human prostate, The Journal of urology, 161 (1999) 635-640. DOI:10.1016/S0022-5347(01)61986-4;

http://www.ncbi.nlm.nih.gov/pubmed/9915474

[8] J.R. Docherty, Subtypes of functional alpha1-adrenoceptor, Cellular and molecular life sciences, $\quad 67 \quad$ (2010) 405-417. $\quad$ DOI:10.1007/s00018-009-0174-4; http://www.ncbi.nlm.nih.gov/pubmed/19862476

[9] N. Kyprianou and C.M. Benning, Suppression of human prostate cancer cell growth by alpha1adrenoceptor antagonists doxazosin and terazosin via induction of apoptosis, Cancer research, 60 (2000) 4550-4555. http://www.ncbi.nlm.nih.gov/pubmed/10969806

[10] S. Thebault, M. Roudbaraki, V. Sydorenko, Y. Shuba, L. Lemonnier, C. Slomianny, E. Dewailly, J.L. Bonnal, B. Mauroy, R. Skryma, and N. Prevarskaya, Alpha1-adrenergic receptors activate $\mathrm{Ca}(2+)$-permeable cationic channels in prostate cancer epithelial cells, The Journal of clinical investigation, $111 \quad$ (2003) 1691-1701. DOI:10.1172/JCI16293; http://www.ncbi.nlm.nih.gov/pubmed/12782672

[11] W. Quaglia, G. Santoni, M. Pigini, A. Piergentili, F. Gentili, M. Buccioni, M. Mosca, R. Lucciarini, C. Amantini, M.I. Nabissi, P. Ballarini, E. Poggesi, A. Leonardi, and M. Giannella, Structure-activity relationships in 1,4-benzodioxan-related compounds. 8.(1) \{2-[2-(4chlorobenzyloxy)phenoxy]ethyl\}-[2-(2,6-dimethoxyphenoxy)ethyl]amine (clopenphendioxan) as a tool to highlight the involvement of alpha1D- and alpha1B-adrenoreceptor subtypes in the regulation of human PC-3 prostate cancer cell apoptosis and proliferation, Journal of medicinal $\begin{array}{llll}\text { chemistry, } & 48 & \text { (2005) 7750-7763. } & \text { DOI:10.1021/jm0580398; }\end{array}$ http://www.ncbi.nlm.nih.gov/pubmed/16302814

[12] T. Shi, R.J. Gaivin, D.F. McCune, M. Gupta, and D.M. Perez, Dominance of the alpha1Badrenergic receptor and its subcellular localization in human and TRAMP prostate cancer cell lines, Journal of receptor and signal transduction research, 27 (2007) 27-45. DOI:10.1080/10799890601087487; http://www.ncbi.nlm.nih.gov/pubmed/17365508

[13] Y. Kojima, S. Sasaki, N. Oda, T.A. Koshimizu, Y. Hayashi, M. Kiniwa, G. Tsujimoto, and K. Kohri, Prostate growth inhibition by subtype-selective alpha(1)-adrenoceptor antagonist naftopidil 
in benign prostatic hyperplasia, The Prostate, 69 (2009) 1521-1528. DOI:10.1002/pros.21003; http://www.ncbi.nlm.nih.gov/pubmed/19544328

[14] Y. Hori, K. Ishii, H. Kanda, Y. Iwamoto, K. Nishikawa, N. Soga, H. Kise, K. Arima, and Y. Sugimura, Naftopidil, a selective \{alpha\}1-adrenoceptor antagonist, suppresses human prostate tumor growth by altering interactions between tumor cells and stroma, Cancer Prevention Research, 4 (2011) 87-96. DOI:10.1158/1940-6207.CAPR-10-0189; http://www.ncbi.nlm.nih.gov/pubmed/21205739

[15] J.A. Garcia-Sainz, J. Vazquez-Prado, and R. Villalobos-Molina, Alpha 1-adrenoceptors: subtypes, signaling, and roles in health and disease, Archives of medical research, 30 (1999) 449458. DOI:10.1016/S0188-0128(99)00059-7; http://www.ncbi.nlm.nih.gov/pubmed/10714357 [16] M.B. Morelli, C. Amantini, M. Nabissi, S. Liberati, C. Cardinali, V. Farfariello, D. Tomassoni, W. Quaglia, A. Piergentili, A. Bonifazi, F. Del Bello, M. Santoni, G. Mammana, L. Servi, A. Filosa, A. Gismondi, and G. Santoni, Cross-talk between alpha1D-adrenoceptors and transient receptor potential vanilloid type 1 triggers prostate cancer cell proliferation, BMC cancer, 14 (2014) DOI:921. 10.1186/1471-2407-14-921; http://www.ncbi.nlm.nih.gov/pubmed/25481381

[17] B. Fulton, A.J. Wagstaff, and E.M. Sorkin, Doxazosin. An update of its clinical pharmacology and therapeutic applications in hypertension and benign prostatic hyperplasia, Drugs, 49 (1995) 295-320. http://www.ncbi.nlm.nih.gov/pubmed/7537194

[18] C.M. Benning and N. Kyprianou, Quinazoline-derived alpha1-adrenoceptor antagonists induce prostate cancer cell apoptosis via an alpha1-adrenoceptor-independent action, Cancer research, 62 (2002) 597-602. http://www.ncbi.nlm.nih.gov/pubmed/11809715

[19] P.D. Walden, Y. Globina, and A. Nieder, Induction of anoikis by doxazosin in prostate cancer cells is associated with activation of caspase- 3 and a reduction of focal adhesion kinase, Urological $\begin{array}{llll}\text { research, } & 32 & \text { (2004) } & \text { 261-265. }\end{array}$ http://www.ncbi.nlm.nih.gov/pubmed/15221243

[20] J.B. Garrison and N. Kyprianou, Doxazosin induces apoptosis of benign and malignant prostate cells via a death receptor-mediated pathway, Cancer research, 66 (2006) 464-472. DOI:10.1158/0008-5472.CAN-05-2039; http://www.ncbi.nlm.nih.gov/pubmed/16397262

[21] A.M. Harris, B.W. Warner, J.M. Wilson, A. Becker, R.G. Rowland, W. Conner, M. Lane, K. Kimbler, E.B. Durbin, A.T. Baron, and N. Kyprianou, Effect of alpha1-adrenoceptor antagonist exposure on prostate cancer incidence: an observational cohort study, The Journal of urology, 178 (2007) 2176-2180.

http://www.ncbi.nlm.nih.gov/pubmed/17870114

DOI:10.1016/j.juro.2007.06.043;

[22] X.L. Rudner, D.E. Berkowitz, J.V. Booth, B.L. Funk, K.L. Cozart, E.B. D'Amico, H. ElMoalem, S.O. Page, C.D. Richardson, B. Winters, L. Marucci, and D.A. Schwinn, Subtype specific regulation of human vascular alpha(1)-adrenergic receptors by vessel bed and age, Circulation, 100 (1999) 2336-2343. http://www.ncbi.nlm.nih.gov/pubmed/10587338

[23] M.C. Beduschi, R. Beduschi, and J.E. Oesterling, Alpha-blockade therapy for benign prostatic hyperplasia: from a nonselective to a more selective alpha1A-adrenergic antagonist, Urology, 51 (1998) 861-872. http://www.ncbi.nlm.nih.gov/pubmed/9609620

[24] J.J. Huang, Y.J. Huang, L. Zhu, M. Yuan, and L. Huang, Design, synthesis and alpha1adrenoreceptor blocking activity of new arylpiperazines containing acetophenone substituents, Die Pharmazie, 69 (2014) 578-584. http://www.ncbi.nlm.nih.gov/pubmed/25158567

[25] S.F. Liou, H.H. Lin, J.C. Liang, I.J. Chen, and J.L. Yeh, Inhibition of human prostate cancer cells proliferation by a selective alpha1-adrenoceptor antagonist labedipinedilol-A involves cell cycle arrest and apoptosis, Toxicology, 256 (2009) 13-24. DOI:10.1016/j.tox.2008.10.025; http://www.ncbi.nlm.nih.gov/pubmed/19056458

[26] H. Kanda, K. Ishii, Y. Ogura, T. Imamura, M. Kanai, K. Arima, and Y. Sugimura, Naftopidil, a selective alpha-1 adrenoceptor antagonist, inhibits growth of human prostate cancer cells by G1 cell cycle arrest, International journal of cancer. Journal international du cancer, 122 (2008) 444-451. DOI:10.1002/ijc.23095; http://www.ncbi.nlm.nih.gov/pubmed/17918159 
[27] A. Gotoh, H. Nagaya, T. Kanno, and T. Nishizaki, Antitumor action of alpha(1)-adrenoceptor blockers on human bladder, prostate and renal cancer cells, Pharmacology, 90 (2012) 242-246. DOI:10.1159/000342797; http://www.ncbi.nlm.nih.gov/pubmed/23007551

[28] D. Yamada, H. Nishimatsu, S. Kumano, Y. Hirano, M. Suzuki, T. Fujimura, H. Fukuhara, Y. Enomoto, H. Kume, and Y. Homma, Reduction of prostate cancer incidence by naftopidil, an alpha1 -adrenoceptor antagonist and transforming growth factor-beta signaling inhibitor, International journal of urology, 20 (2013) 1220-1227. DOI:10.1111/iju.12156; http://www.ncbi.nlm.nih.gov/pubmed/23600973

[29] J. Huang, F. He, M. Huang, X. Liu, Y. Xiong, Y. Huang, L. Zhu, Y. Yang, X. Xu, and M. Yuan, Novel naftopidil-related derivatives and their biological effects as alpha1-adrenoceptors antagonists and antiproliferative agents, European journal of medicinal chemistry, 96 (2015) 8391. DOI:10.1016/j.ejmech.2015.04.005; http://www.ncbi.nlm.nih.gov/pubmed/25874333

[30] W. Quaglia, A. Piergentili, F. Del Bello, Y. Farande, M. Giannella, M. Pigini, G. Rafaiani, A. Carrieri, C. Amantini, R. Lucciarini, G. Santoni, E. Poggesi, and A. Leonardi, Structure-activity relationships in 1,4-benzodioxan-related compounds. 9. From 1,4-benzodioxane to 1,4-dioxane ring as a promising template of novel alpha1D-adrenoreceptor antagonists, 5-HT1A full agonists, and cytotoxic agents, Journal of medicinal chemistry, 51 (2008) 6359-6370. DOI:10.1021/jm800461k; http://www.ncbi.nlm.nih.gov/pubmed/18817363

[31] A. Bonifazi, A. Piergentili, F. Del Bello, Y. Farande, M. Giannella, M. Pigini, C. Amantini, M. Nabissi, V. Farfariello, G. Santoni, E. Poggesi, A. Leonardi, S. Menegon, and W. Quaglia, Structure-activity relationships in 1,4-benzodioxan-related compounds. 11. (1) reversed enantioselectivity of 1,4-dioxane derivatives in alpha1-adrenergic and 5-HT1A receptor binding sites recognition, Journal of medicinal chemistry, 56 (2013) 584-588. DOI:10.1021/jm301525w; http://www.ncbi.nlm.nih.gov/pubmed/23252794

[32] L. Villa, E. Valoti, A.M. Villa, M. Pallavicini, V. Ferri, E. Iuliano, and N. Brunello, Molecular properties of the WB4101 enantiomers and of its chiral methyl derivatives for alpha 1-adrenoceptor recognition, Farmaco, 49 (1994) 587-606. http://www.ncbi.nlm.nih.gov/pubmed/7811353

[33] L. Fumagalli, C. Bolchi, S. Colleoni, M. Gobbi, B. Moroni, M. Pallavicini, A. Pedretti, L. Villa, G. Vistoli, and E. Valoti, QSAR study for a novel series of ortho monosubstituted phenoxy analogues of alpha1-adrenoceptor antagonist WB4101, Bioorganic \& medicinal chemistry, 13 (2005) 2547-2559.

DOI:10.1016/j.bmc.2005.01.034;

http://www.ncbi.nlm.nih.gov/pubmed/15755656

[34] M. Pallavicini, R. Budriesi, L. Fumagalli, P. Ioan, A. Chiarini, C. Bolchi, M.P. Ugenti, S. Colleoni, M. Gobbi, and E. Valoti, WB4101-related compounds: new, subtype-selective alpha1adrenoreceptor antagonists (or inverse agonists?), Journal of medicinal chemistry, 49 (2006) DOI:7140-7149. 10.1021/jm060358r; http://www.ncbi.nlm.nih.gov/pubmed/17125266

[35] M. Pallavicini, L. Fumagalli, M. Gobbi, C. Bolchi, S. Colleoni, B. Moroni, A. Pedretti, C. Rusconi, G. Vistoli, and E. Valoti, QSAR study for a novel series of ortho disubstituted phenoxy analogues of alpha1-adrenoceptor antagonist WB4101, European journal of medicinal chemistry, 41 (2006) 1025-1040. DOI:10.1016/j.ejmech.2006.04.004; http://www.ncbi.nlm.nih.gov/pubmed/16737760

[36] L. Fumagalli, M. Pallavicini, R. Budriesi, M. Gobbi, V. Straniero, M. Zagami, G. Chiodini, C. Bolchi, A. Chiarini, M. Micucci, and E. Valoti, Affinity and activity profiling of unichiral 8substituted 1,4-benzodioxane analogues of WB4101 reveals a potent and selective alpha1Badrenoceptor antagonist, European journal of medicinal chemistry, 58 (2012) 184-191. DOI:10.1016/j.ejmech.2012.09.049; http://www.ncbi.nlm.nih.gov/pubmed/23124215

[37] L. Fumagalli, M. Pallavicini, R. Budriesi, C. Bolchi, M. Canovi, A. Chiarini, G. Chiodini, M. Gobbi, P. Laurino, M. Micucci, V. Straniero, and E. Valoti, 6-methoxy-7-benzofuranoxy and 6methoxy-7-indolyloxy analogues of 2-[2-(2,6-Dimethoxyphenoxy)ethyl]aminomethyl-1,4benzodioxane (WB4101):1 discovery of a potent and selective alpha1D-adrenoceptor antagonist, 
Journal of medicinal chemistry, 56 (2013) 6402-6412. DOI:10.1021/jm400867d; http://www.ncbi.nlm.nih.gov/pubmed/23902232

[38] U. Varol, M. Degirmenci, B. Karaca, H. Atmaca, A. Kisim, S. Uzunoglu, C. Sezgin, U.A. Sanli, and R. Uslu, Zoledronic acid increases cytotoxicity by inducing apoptosis in hormone and docetaxel-resistant prostate cancer cell lines, Tumour biology, 36 (2015) 779-786. DOI:10.1007/s13277-014-2682-6; http://www.ncbi.nlm.nih.gov/pubmed/25293519

[39] P. Chomczynski and N. Sacchi, Single-step method of RNA isolation by acid guanidinium thiocyanate-phenol-chloroform extraction, Analytical biochemistry, 162 (1987) 156-159. DOI:10.1006/abio.1987.9999; http://www.ncbi.nlm.nih.gov/pubmed/2440339

[40] K.J. Livak and T.D. Schmittgen, Analysis of relative gene expression data using real-time quantitative PCR and the 2(-Delta Delta C(T)) Method, Methods, 25 (2001) 402-408. DOI:10.1006/meth.2001.1262; http://www.ncbi.nlm.nih.gov/pubmed/11846609

[41] J. Tseng-Crank, T. Kost, A. Goetz, S. Hazum, K.M. Roberson, J. Haizlip, N. Godinot, C.N. Robertson, and D. Saussy, The alpha 1C-adrenoceptor in human prostate: cloning, functional expression, and localization to specific prostatic cell types, British journal of pharmacology, 115 (1995) 1475-1485. http://www.ncbi.nlm.nih.gov/pubmed/8564208

[42] J.A. Garcia-Sainz and R. Villalobos-Molina, The elusive alpha(1D)-adrenoceptor: molecular and cellular characteristics and integrative roles, European journal of pharmacology, 500 (2004) 113-120. DOI:10.1016/j.ejphar.2004.07.016; http://www.ncbi.nlm.nih.gov/pubmed/15464025

[43] L. Cheng, R.V. Lloyd, A.L. Weaver, T.M. Pisansky, J.C. Cheville, D.M. Ramnani, B.C. Leibovich, M.L. Blute, H. Zincke, and D.G. Bostwick, The cell cycle inhibitors p21WAF1 and p27KIP1 are associated with survival in patients treated by salvage prostatectomy after radiation $\begin{array}{llllll}\text { therapy, } & \text { Clinical } & \text { cancer } & \text { research, } & 6 & \text { (2000) }\end{array}$ http://www.ncbi.nlm.nih.gov/pubmed/10815913

[44] J. Tsihlias, L. Kapusta, and J. Slingerland, The prognostic significance of altered cyclindependent kinase inhibitors in human cancer, Annual review of medicine, 50 (1999) 401-423. DOI:10.1146/annurev.med.50.1.401; http://www.ncbi.nlm.nih.gov/pubmed/10073286

[45] Z. Hu, D. Zhang, J. Hao, K. Tian, W. Wang, H. Lou, and H. Yuan, Induction of DNA damage and p21-dependent senescence by Riccardin D is a novel mechanism contributing to its growth suppression in prostate cancer cells in vitro and in vivo, Cancer chemotherapy and

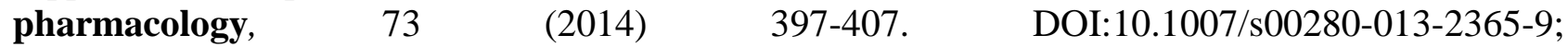
http://www.ncbi.nlm.nih.gov/pubmed/24322375

[46] O. Tavana, C.L. Benjamin, N. Puebla-Osorio, M. Sang, S.E. Ullrich, H.N. Ananthaswamy, and C. Zhu, Absence of p53-dependent apoptosis leads to UV radiation hypersensitivity, enhanced immunosuppression and cellular senescence, Cell Cycle, 9 (2010) 3328-3336. DOI:10.4161/cc.9.16.12688; http://www.ncbi.nlm.nih.gov/pubmed/20703098

[47] T.L.t. Drell, J. Joseph, K. Lang, B. Niggemann, K.S. Zaenker, and F. Entschladen, Effects of neurotransmitters on the chemokinesis and chemotaxis of MDA-MB-468 human breast carcinoma cells, Breast cancer research and treatment, 80 (2003) 63-70. DOI:10.1023/A:1024491219366; http://www.ncbi.nlm.nih.gov/pubmed/12889599

[48] K. Mori, H. Hamanaka, Y. Oshima, Y. Araki, F. Ishikawa, K. Nose, and M. Shibanuma, A HIC-5- and KLF4-dependent mechanism transactivates p21(Cip1) in response to anchorage loss, The Journal of biological chemistry, 287 (2012) 38854-38865. DOI:10.1074/jbc.M112.377721; http://www.ncbi.nlm.nih.gov/pubmed/23007394

[49] P.J. Hensley, A. Desiniotis, C. Wang, A. Stromberg, C.S. Chen, and N. Kyprianou, Novel pharmacologic targeting of tight junctions and focal adhesions in prostate cancer cells, PloS one, 9 (2014) e86238. 10.1371/journal.pone.0086238; http://www.ncbi.nlm.nih.gov/pubmed/24497940

[50] J.B. Garrison, Y.J. Shaw, C.S. Chen, and N. Kyprianou, Novel quinazoline-based compounds impair prostate tumorigenesis by targeting tumor vascularity, Cancer research, 67 (2007) 1134411352. DOI:10.1158/0008-5472.CAN-07-1662; http://www.ncbi.nlm.nih.gov/pubmed/18056461 
[51] K. Keledjian and N. Kyprianou, Anoikis induction by quinazoline based alpha 1-adrenoceptor antagonists in prostate cancer cells: antagonistic effect of bcl-2, The Journal of urology, 169 (2003) $1150-1156$.

DOI:10.1097/01.ju.0000042453.12079.77; http://www.ncbi.nlm.nih.gov/pubmed/12576871

[52] S.Y. Wang, Y. Song, M. Xu, Q.H. He, Q.D. Han, and Y.Y. Zhang, Internalization and distribution of three alpha1-adrenoceptor subtypes in HEK293A cells before and after agonist stimulation, Acta pharmacologica Sinica, 28 (2007) 359-366. DOI:10.1111/j.17457254.2007.00509.x; http://www.ncbi.nlm.nih.gov/pubmed/17302998

[53] D.F. McCune, S.E. Edelmann, J.R. Olges, G.R. Post, B.A. Waldrop, D.J. Waugh, D.M. Perez, and M.T. Piascik, Regulation of the cellular localization and signaling properties of the alpha(1B)and alpha(1D)-adrenoceptors by agonists and inverse agonists, Molecular pharmacology, 57 (2000) 659-666. DOI: 10.1124/mol.57.4.659; http://www.ncbi.nlm.nih.gov/pubmed/10727510

[54] C. Hague, S.E. Lee, Z. Chen, S.C. Prinster, R.A. Hall, and K.P. Minneman, Heterodimers of alpha1B- and alpha1D-adrenergic receptors form a single functional entity, Molecular $\begin{array}{lllll}\text { pharmacology, } & 69 & \text { (2006) } & 45-55 . & \text { DOI:10.1124/mol.105.014985; }\end{array}$

http://www.ncbi.nlm.nih.gov/pubmed/16195468 


\section{LEGEND TO FIGURES}

Figure 1: relative expression levels of the three main alpha1-AR in different human prostate cancer cell lines.

Panel A: relative expression of alpha1A-AR, alpha1B-AR and alpha1D-AR in LNCaP, Rv1, PC3 and DU145 cells. The expression level of each AR subtype has been quantified by the $2^{-\Delta \Delta \mathrm{Ct}}$ method using RNA pooled from all PC cells as calibrator. Panel B: relative expression of alpha1B-AR and alpha1D-AR in PC3 and DU145 cells. The expression level of each AR subtype has been quantified by the $2^{-\Delta \Delta C t}$ method using total RNA pooled from PC3 and DU145 cells as calibrator.

Figure 2: Inhibitory action of A175 on androgen-independent PC cell proliferation.

Cell proliferation has been evaluated by BrdU incorporation into DNA. Data are expressed as mean \pm SD of adsorbance at $450 \mathrm{~nm}(\mathrm{rlu} / \mathrm{sec})$. Panel A: PC3 cells maintained in starved conditions (FCS 1\%,) exposed to graded A175 concentrations $(1-75 \mu \mathrm{M})$ for 48 hours. ${ }^{*} \mathrm{p}<0,01$

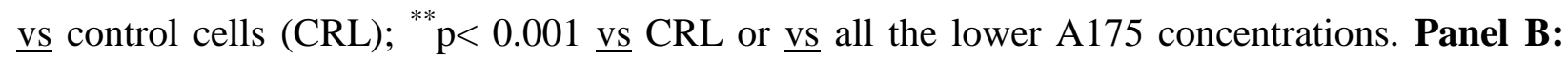
PC3 and DU145 cells maintained in growth stimulating conditions (FCS 10\%) exposed to different A175 concentrations $(25$ and $50 \mu \mathrm{M})$ for 48 hours. ${ }^{*} \mathrm{p}<0.05$ vs control cells (CRL); ${ }^{* *} \mathrm{p}<0.001$ vs $\mathrm{CRL} ;{ }^{\S} \mathrm{p}<0.05 \underline{\text { vs }}$ A175 $25 \mu \mathrm{M}$.

Figure 3: Inhibitory action of A175 on PC3 cell growth in presence of phenylephrine (Phe) or phenoxybenzamine (PBA).

Cell proliferation has been evaluated by BrdU incorporation into DNA after a $48 \mathrm{~h}$ exposure to A175. Data are expressed as mean \pm SD of adsorbance at $450 \mathrm{~nm}(\mathrm{rlu} / \mathrm{sec})$. Panel A: Cells maintained in FCS $10 \%$ were treated with A175 25 or $50 \mu \mathrm{M}$ with or without phenylephrine 50 $\mu$ M. Panel B: Cells maintained in FCS $10 \%$ were exposed to vehicle (left side) or to 
phenoxybenzamine $1 \mu \mathrm{M}$ (right side) $4 \mathrm{~h}$ prior to the addition of $\mathrm{A} 17525$ or $50 \mu \mathrm{M} .{ }^{\mathrm{a}} \mathrm{p}<0.05 \underline{\mathrm{vs}}$ the respective untreated controls; ${ }^{b} \mathrm{p}<0.001 \underline{\text { vs }}$ the respective untreated controls; ${ }^{c} \mathrm{p}<0.001 \underline{\mathrm{vs}}$ A175 $25 \mu \mathrm{M} ;{ }^{\mathrm{d}} \mathrm{p}<0.01$ vs Phe $50 \mu \mathrm{M} ;{ }^{\mathrm{e}} \mathrm{p}<0.001$ vs Phe $50 \mu \mathrm{M} ;{ }^{\mathrm{f}} \mathrm{p}<0.001$ vs Phe $50 \mu \mathrm{M}+\mathrm{A} 175$ $25 \mu \mathrm{M} ;{ }^{\mathrm{g}} \mathrm{p}<0.05 \underline{\text { vs }} \mathrm{A} 17525 \mu \mathrm{M}$ w/o PBA.

Figure 4: Cell cycle analysis and p27 and p21 levels in PC3 and DU145 cells exposed to A175.

Panel A: representative histograms of each experimental group and cumulative results of the \% distribution along cell cycle in PC3 cells; ${ }^{* *} \mathrm{p}<0.01$ vs controls $(\mathrm{CRL})$. Panel C: representative histograms of each experimental group and cumulative results of the $\%$ distribution along cell cycle in DU145 cells. Panel B: representative Western blot of p27 and p21 levels in PC3 cells and densitometric analysis of all the samples analyzed. Data are expressed as mean $\%$ variation \pm SD of relative optic densities (MOD), normalized for beta-actin, vs controls. Panel D: representative Western blot of p27 and p21 levels in DU145 cells and corresponding densitometric analysis. Data are expressed as \% variation of relative optic densities (MOD), normalized for beta-actin, $\underline{\text { vs }}$ controls.

Figure 5: Effect of A175 on PC3 and DU145 cell motility.

PC3 (panel A) and DU145 (panel B) cells were treated with A175 10 or $50 \mu \mathrm{M}$ for $48 \mathrm{~h}$ and than used to evaluate microchemotaxis in presence of FCS $1 \%$ as chemoattractant (Boyden's chamber assay, overnight migration at $37 \mathrm{C}^{\circ}$ ). Untreated cells in presence of DMEM represent the spontaneous chemokinetic activity. Data are expressed as mean \pm SD of the number of migrated cells $/ \mathrm{mm}^{2} . * * \mathrm{p}<0.001$ vs control cells (FCS 1\% CTR).

Figure 6: Effect of A175 on PC3 cell attachment on uncoated Petri dishes. 
PC3 cells were exposed to A175 10 or $50 \mu \mathrm{M}$ for $48 \mathrm{~h}$, harvested and seeded at the same density on uncoated new culture plates. After $4 \mathrm{~h}$ incubation, the number of attached cells was assessed by MTT assay. The data are expressed as mean \pm SD $\%$ of treated vs control cells (CTR). ${ }^{* *} \mathrm{p}<$ $0.001 \underline{\text { vs }}$ CTR; ${ }^{\S} \mathrm{p}<0.001 \underline{\text { vs }}$ A175 $10 \mu \mathrm{M}$.

Figure 7: immunofluorescence and confocal microscopy of alpha1D-AR in PC3 cells exposed to 25 or $50 \mu \mathrm{M}$ A 175 , for $48 \mathrm{~h}$.

Alpha1D-AR immunopositivity is localized in small spots in the nucleus and in the perinuclear region $\left(^{*}\right)$ in control cells and in larger spots in the whole cell body (**) in A175 exposed cells. 
Figure 1
Click here to download high resolution image

A)

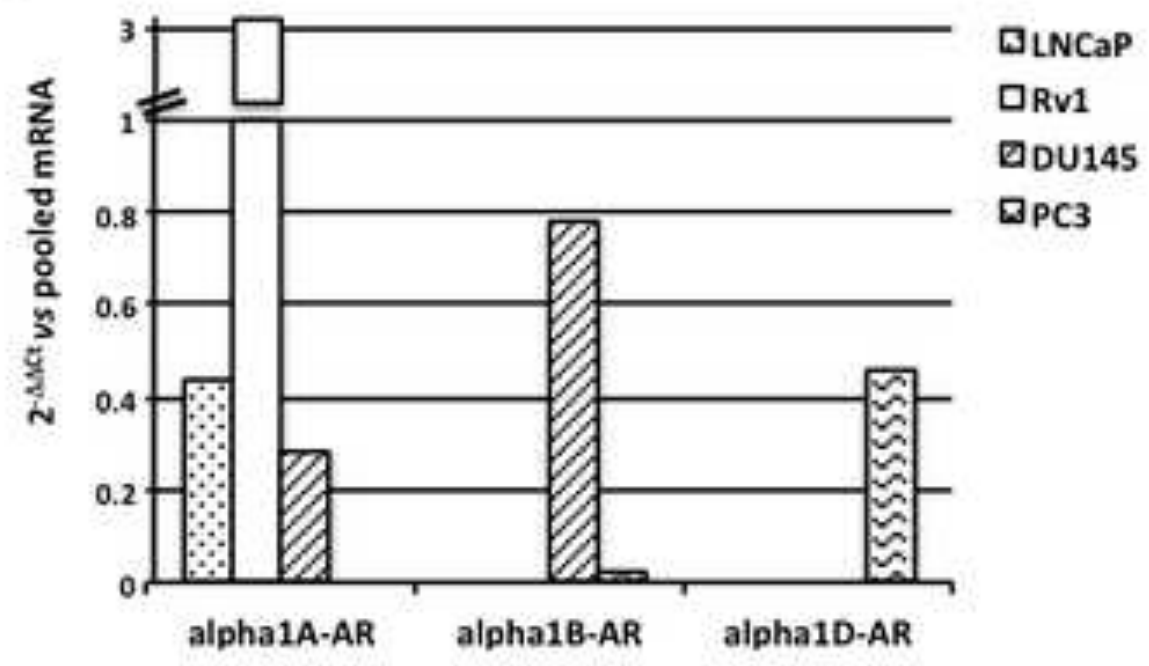

B)

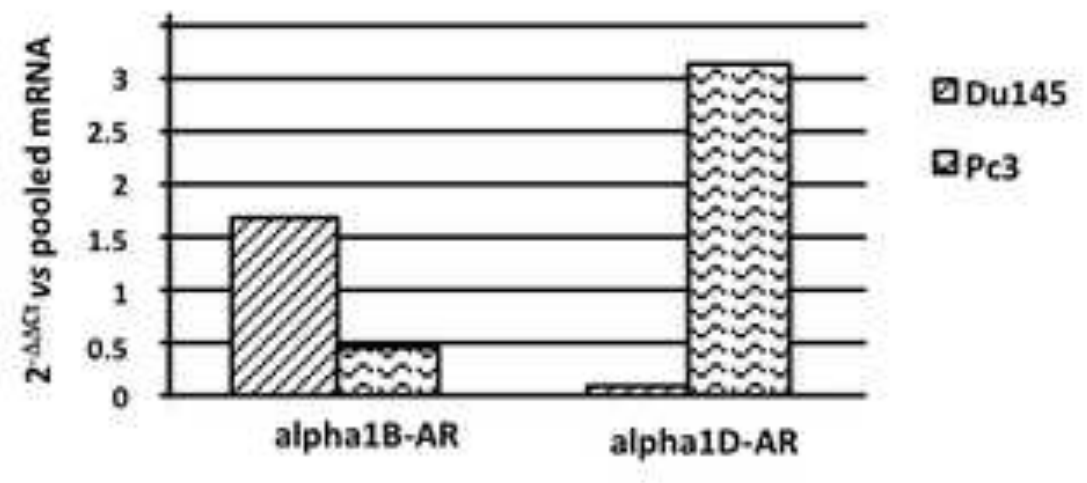


Figure 2

Click here to download high resolution image

A)

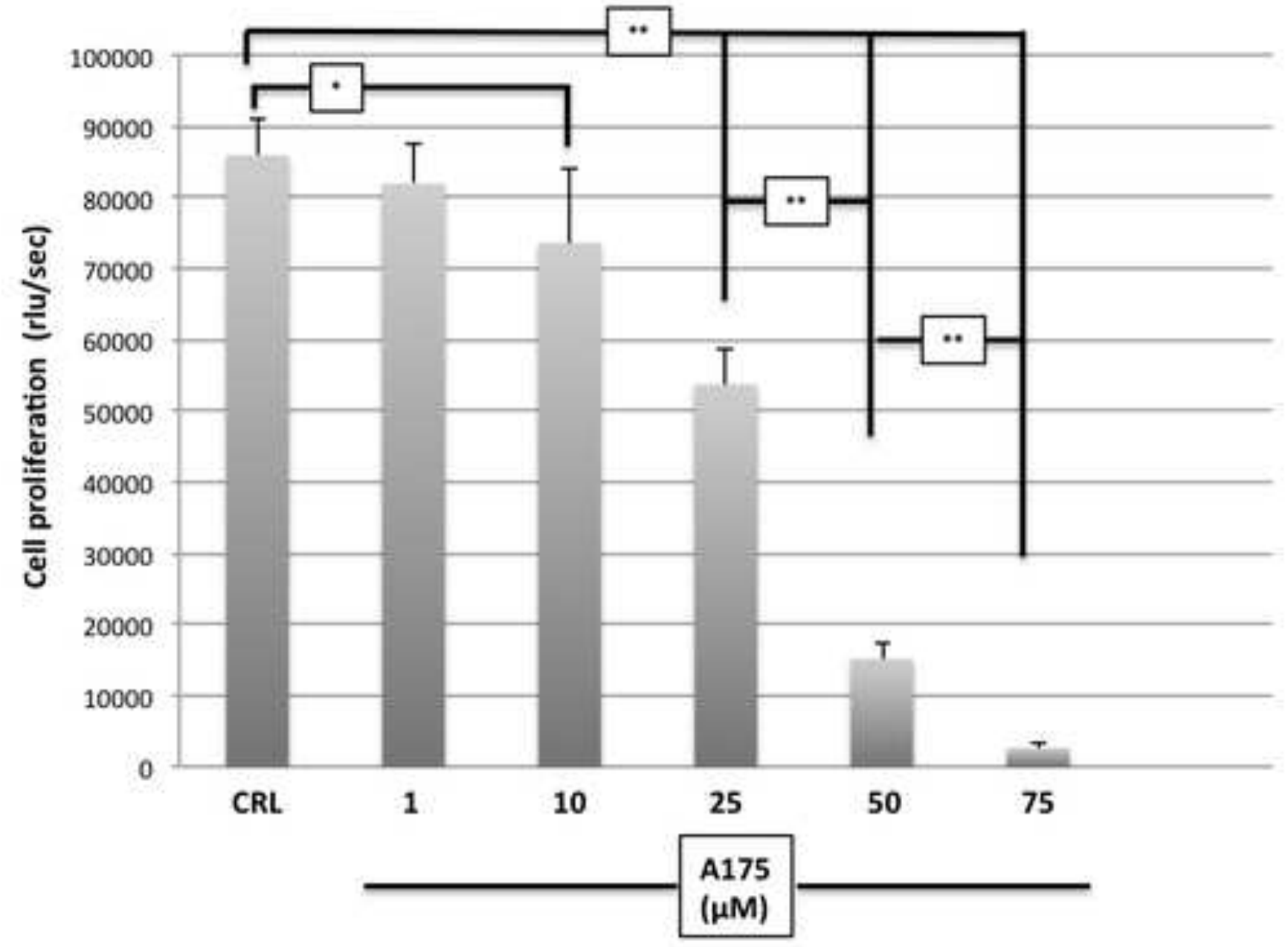

B)

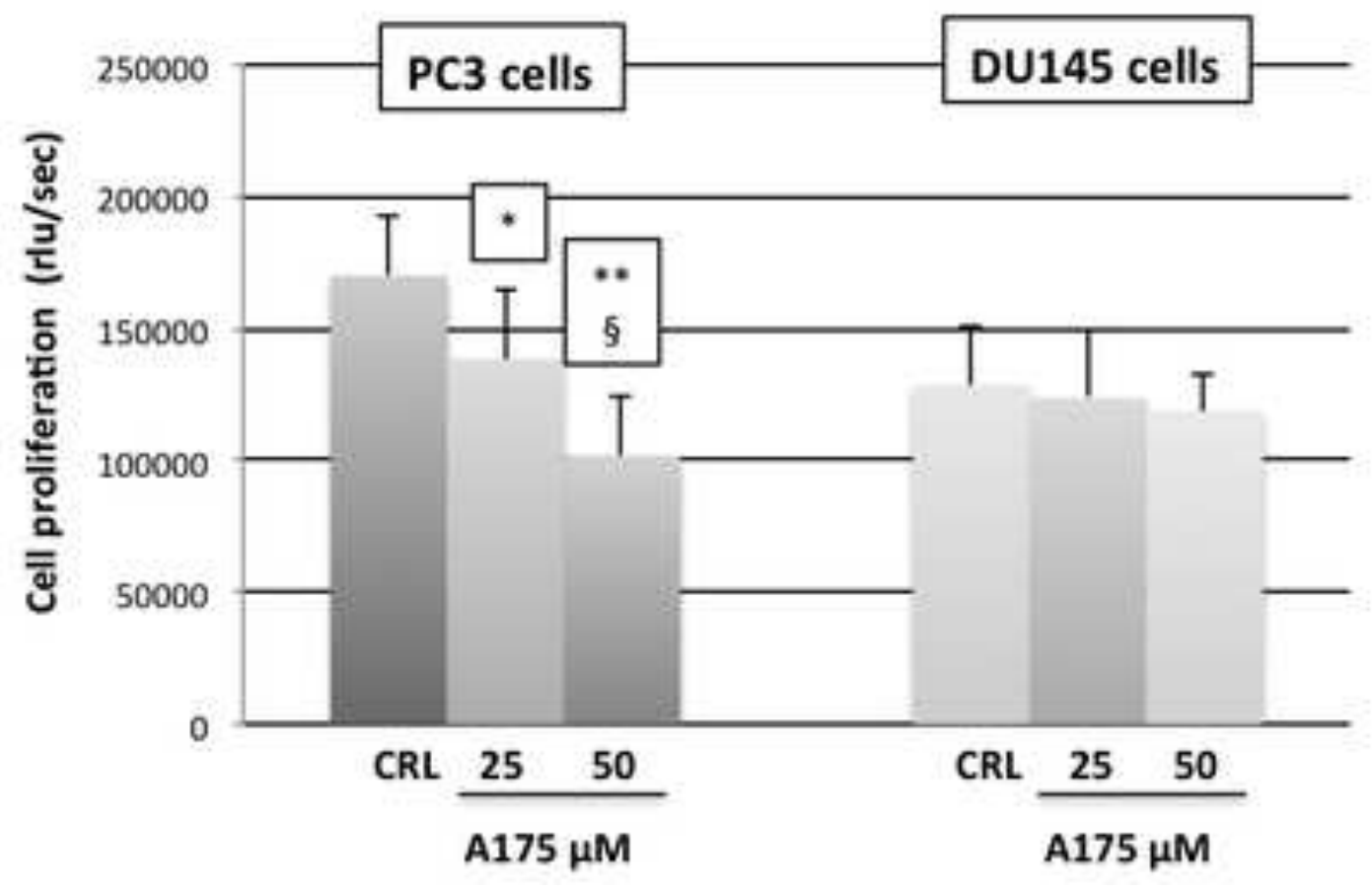




\section{Figure 3}

Click here to download high resolution image

A)

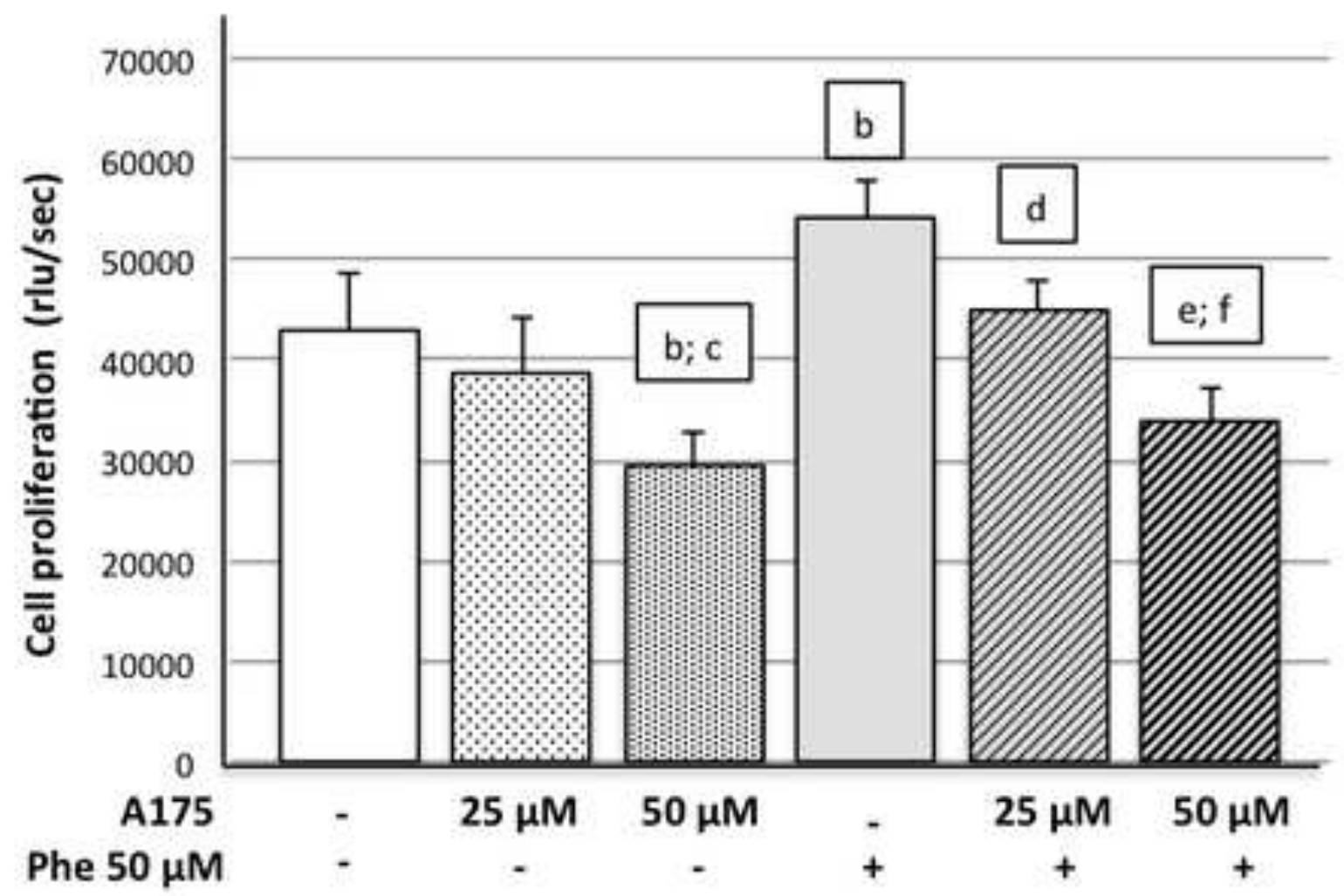

B)

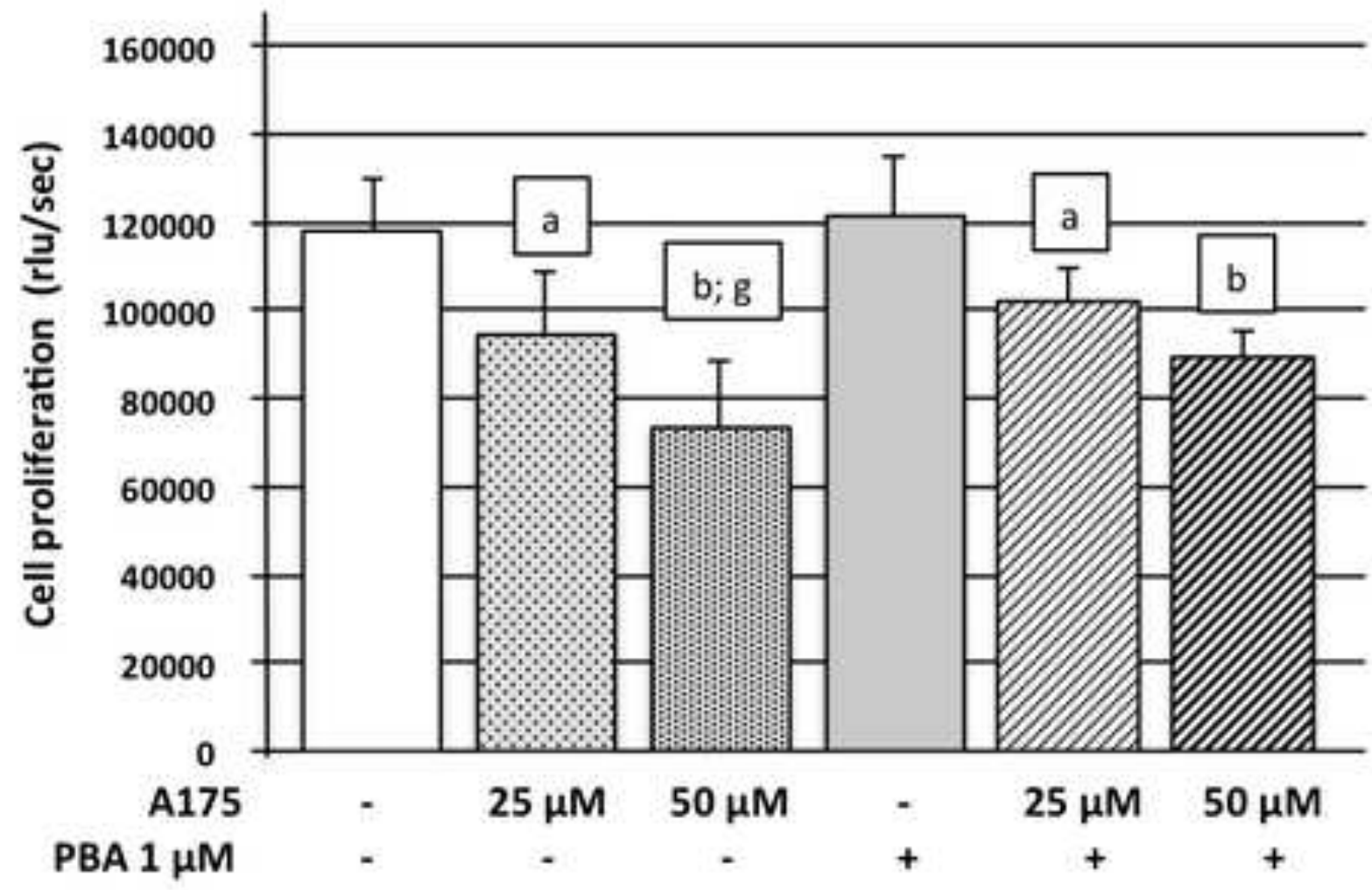




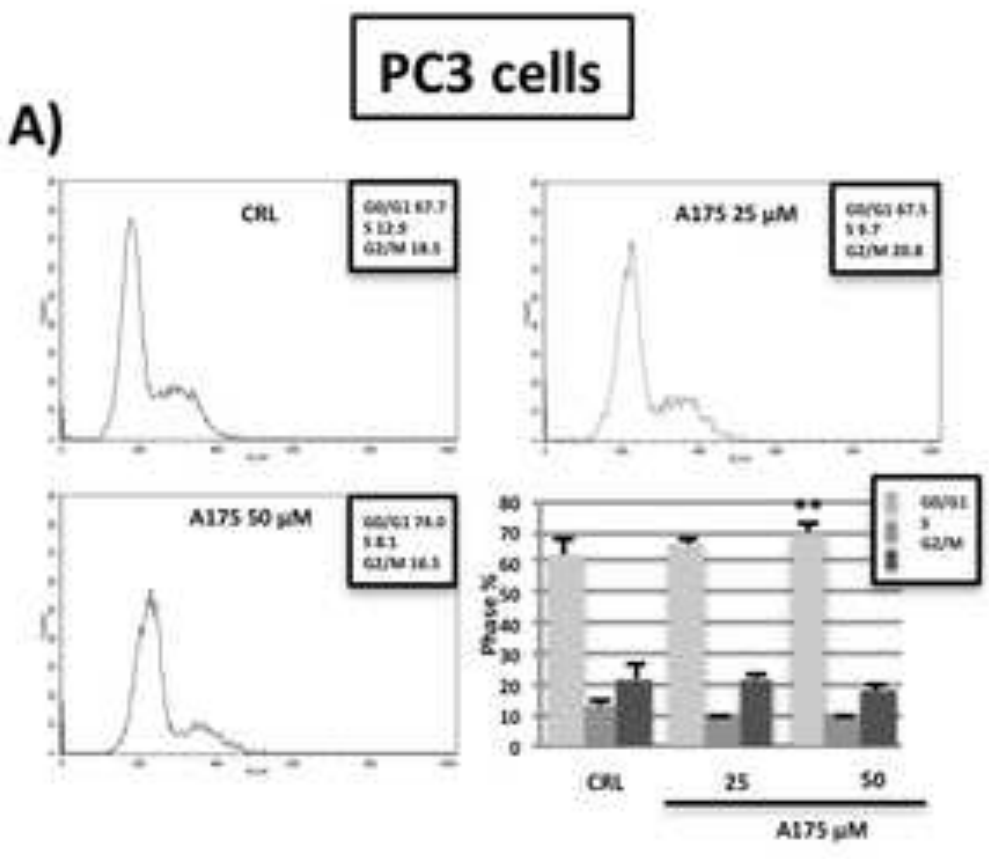

B)
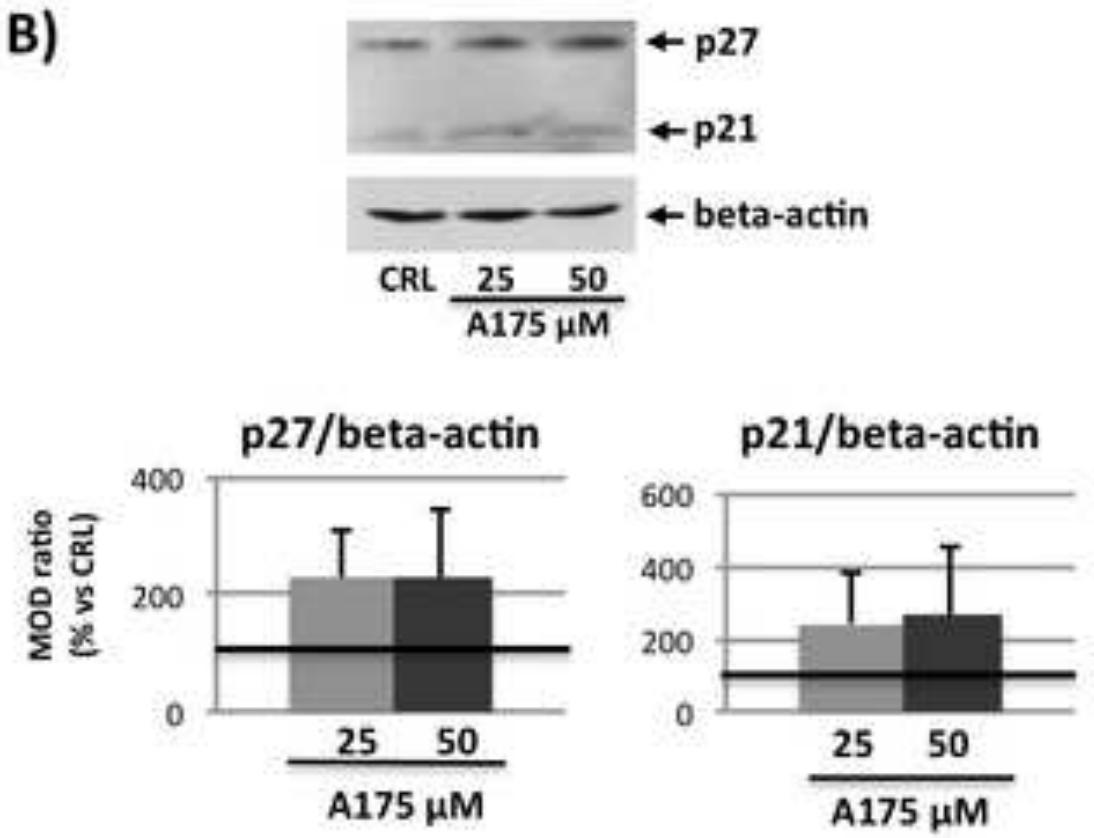

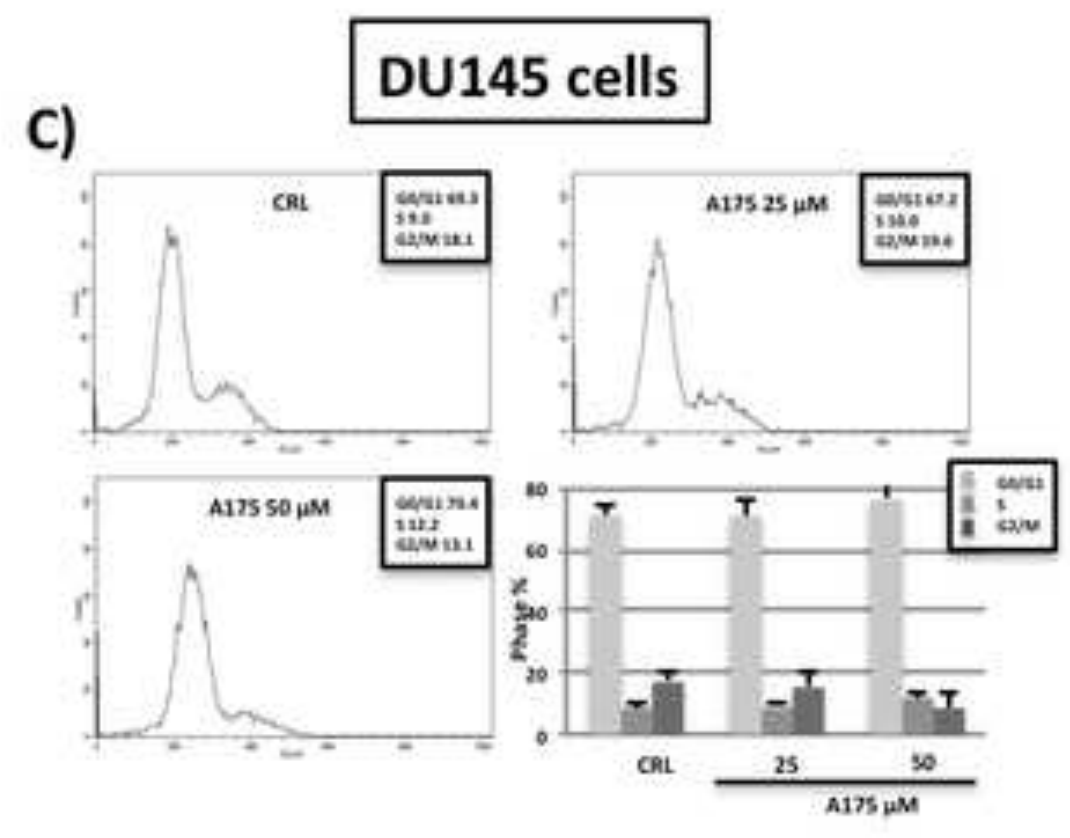

D)
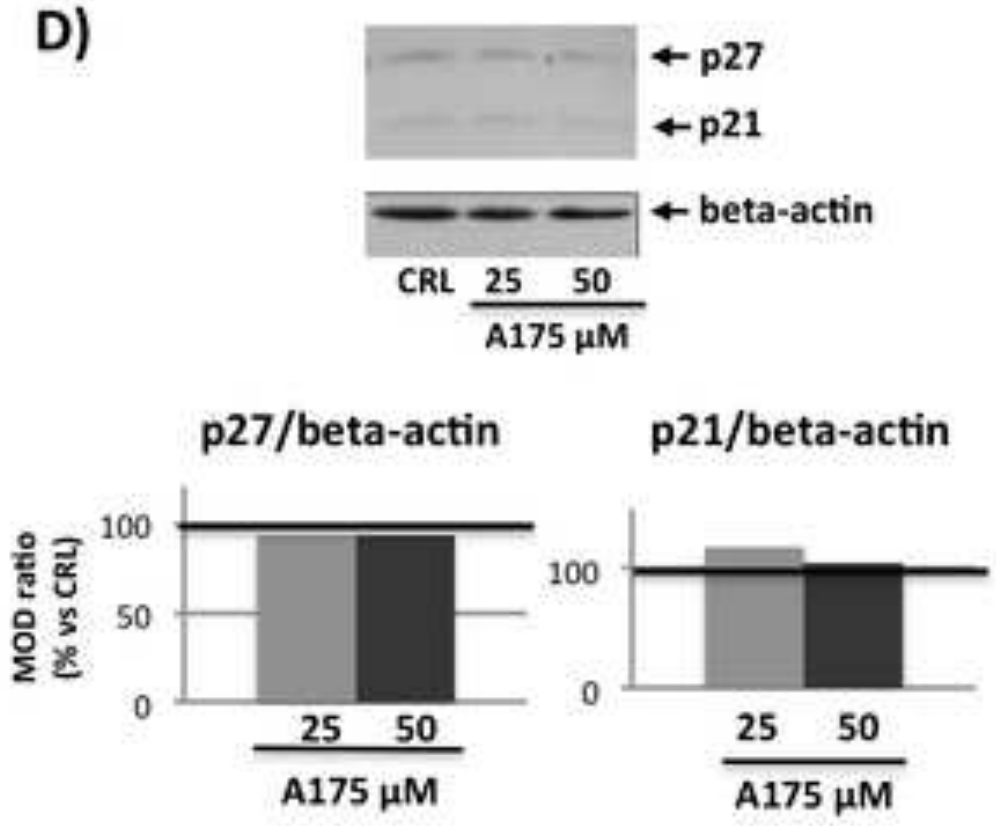


\section{Figure 5}

Click here to download high resolution image

A) PC3 cells

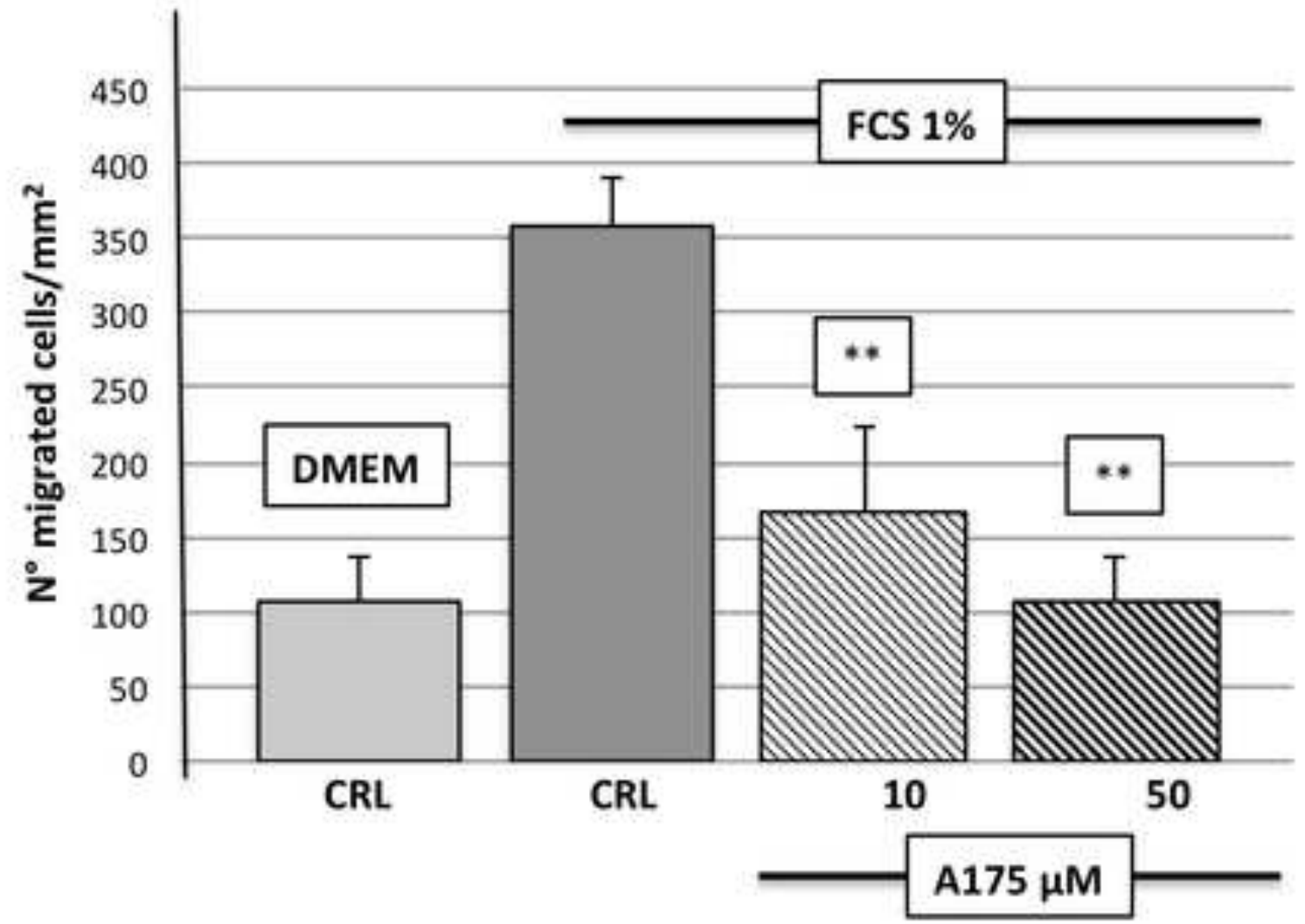

B) DU145 cells

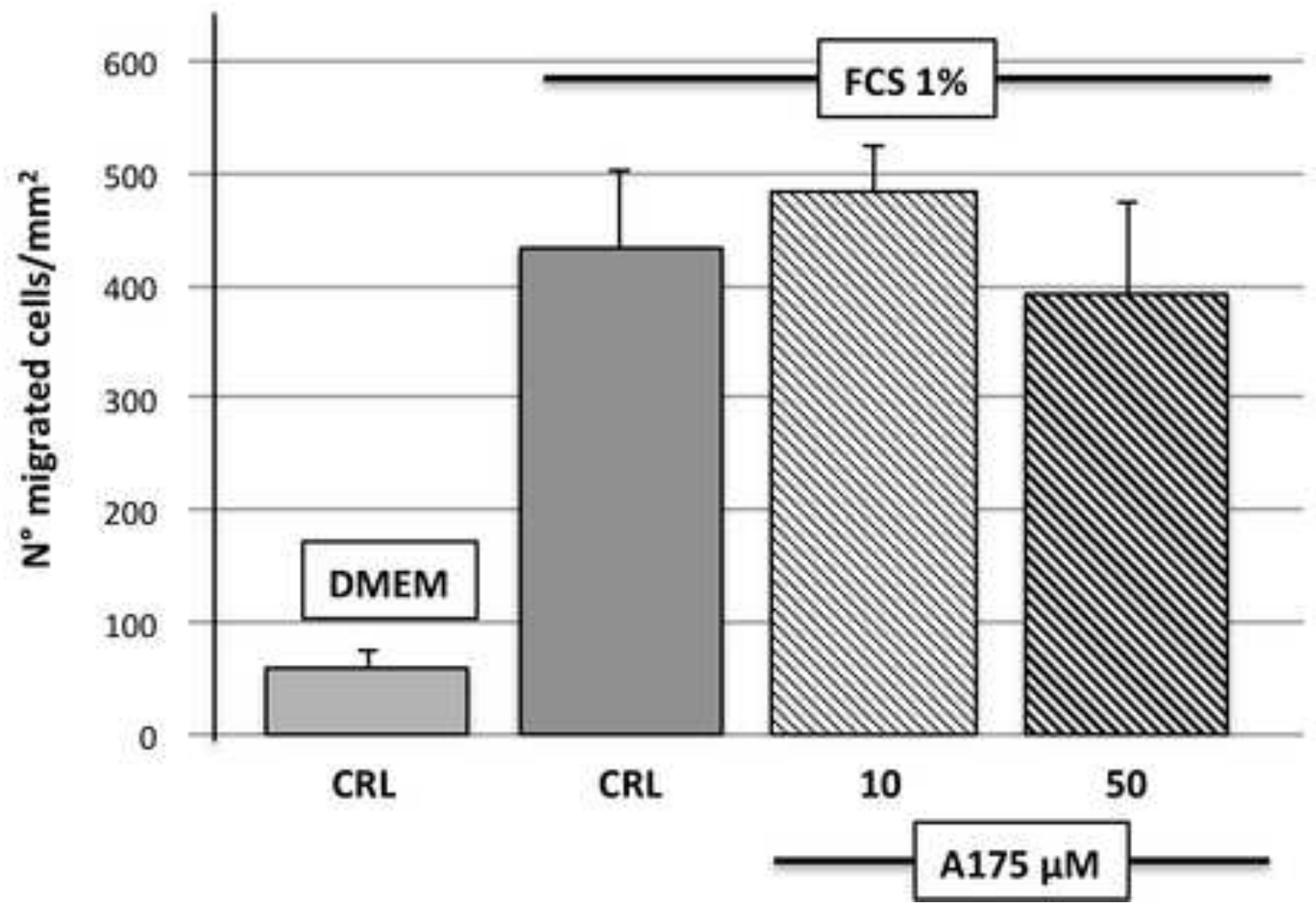




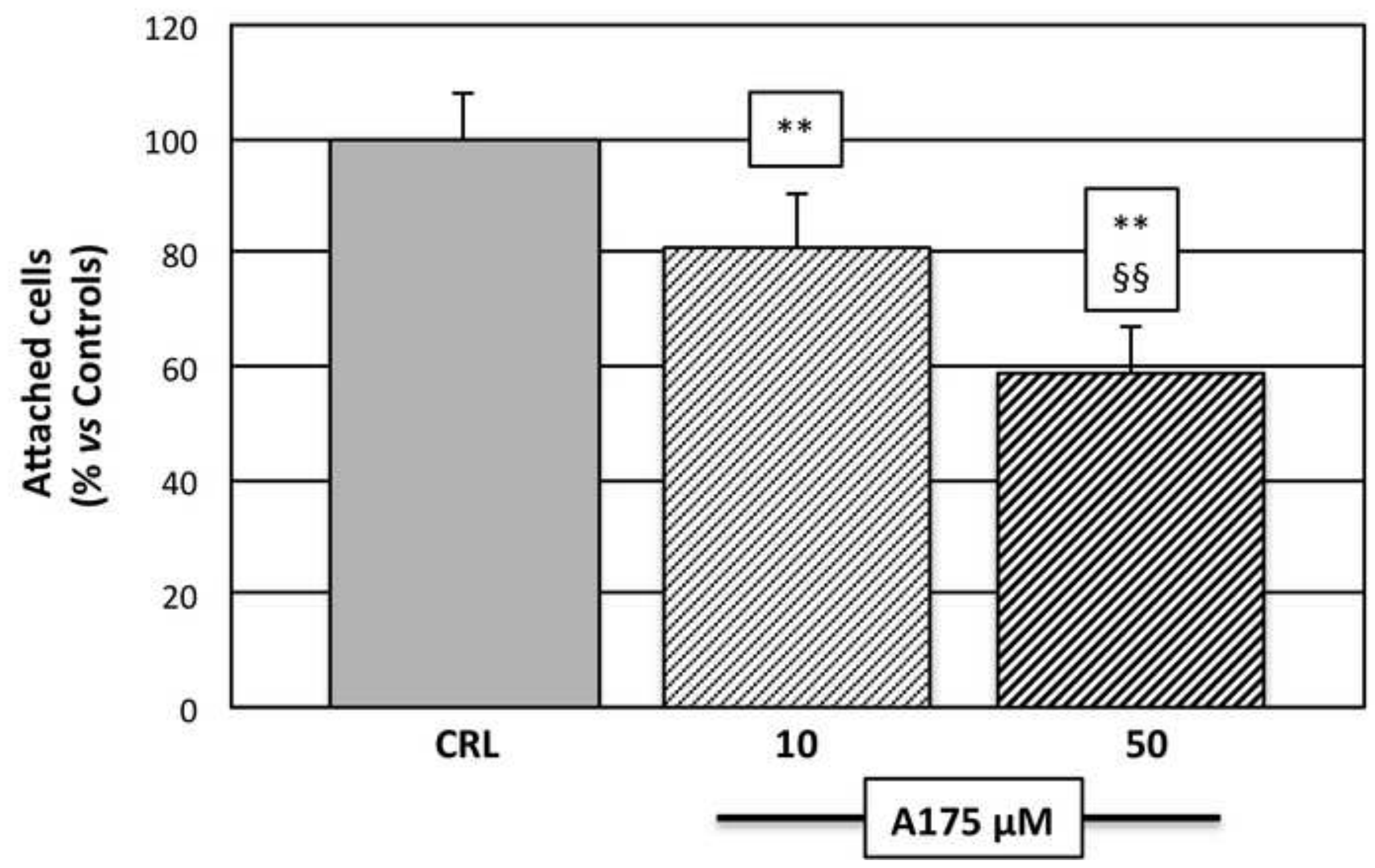


Figure 7
Click here to download high resolution image

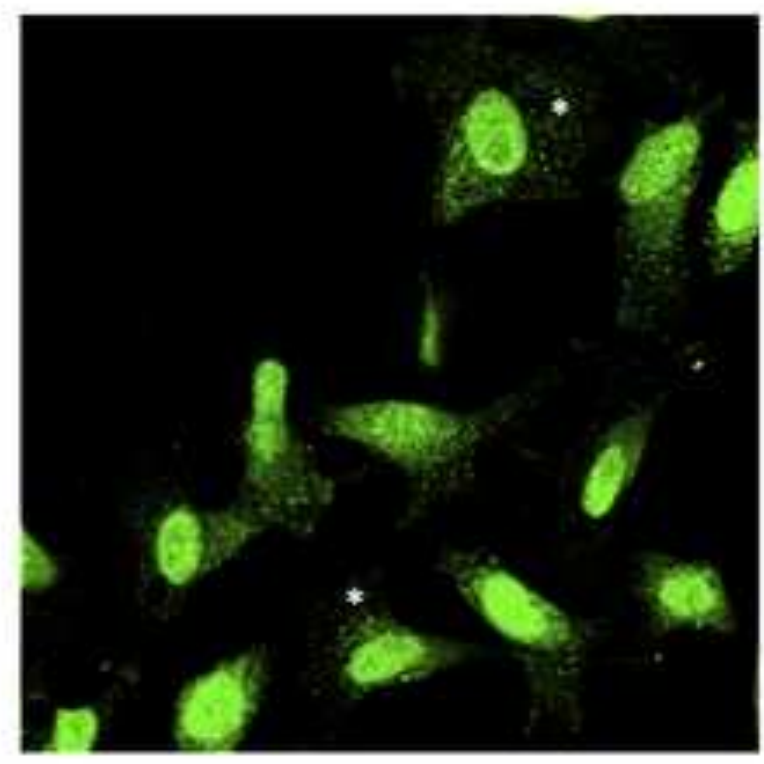

CRL

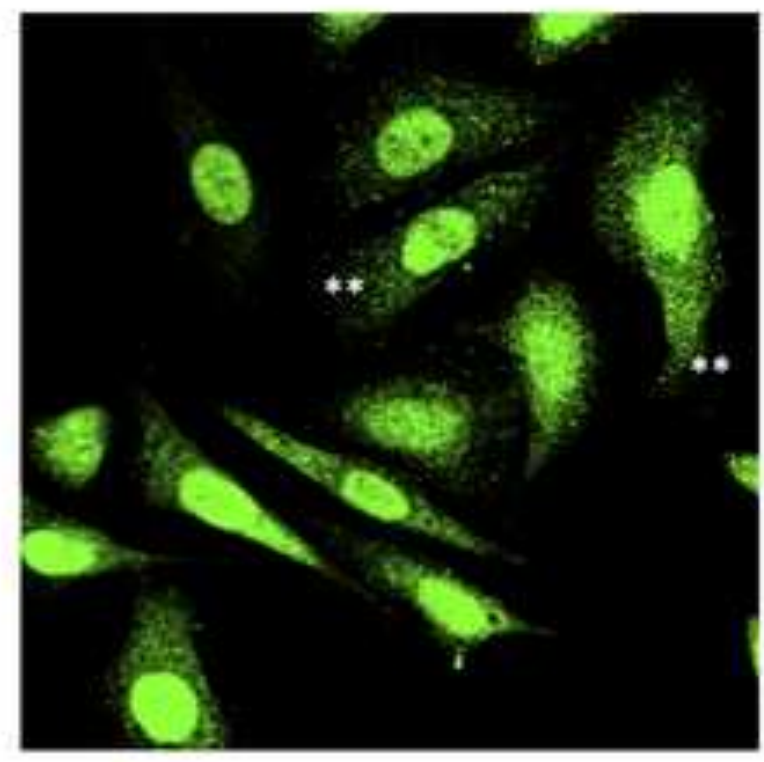

$\mathrm{A} 17525 \mu \mathrm{M}$

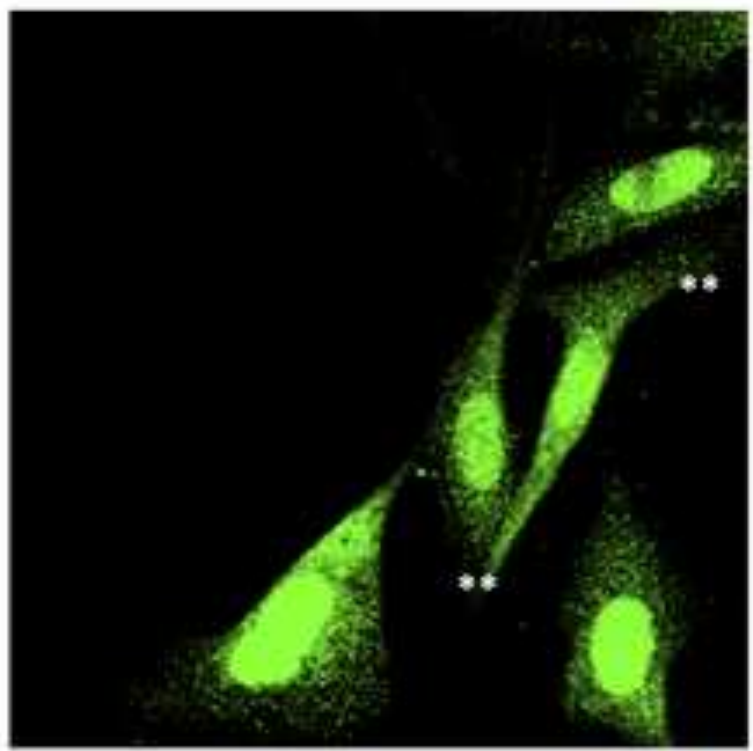

A175 $50 \mu \mathrm{M}$ 